\title{
SEDIMENTOLOGICAL FEATURES AND DEPOSITIONAL CONDITIONS OF ACCUMULATIVE FANS IN THE LOWER SERTEYKA RIVER VALLEY, WESTERN RUSSIA
}

\author{
WIKTOR PIECH
}

\begin{abstract}
In the Serteyka River valley in western Russia, eight accumulative fans formed at the mouths of ravines were examined geologically and geomorphologically. The test samples were collected from individual geological drillings made with a manual probe, as well as from excavations in the central and distal zones of the fans. Using the Gradistat program, sedimentological indicators were calculated, i.e. mean grain diameter $\left(\mathrm{M}_{\mathrm{Z}}\right)$, standard deviation (sorting $\left.-\sigma_{\mathrm{I}}\right)$, skewness $\left(\mathrm{Sk}_{\mathrm{I}}\right)$ and kurtosis $\left(\mathrm{K}_{\mathrm{G}}\right)$, and then particle-size distribution frequency curves, cumulative curves and a Passega $\mathrm{C} / \mathrm{M}$ diagram were drawn. It has been documented that the grain size of the fan sediments depends on the characteristics of the source material. Analysis of sedimentological indicators (mean grain diameter, sorting, skewness, kurtosis) showed the studied fans deposits to have a large variability of erosion and accumulation conditions. For the deposits of younger fans, the $2^{\text {nd }}$ system of the Mz-versus- $\sigma_{I}$ relationship after MycielskaDowgiałło (1995) was distinguished, while for the older, the $2^{\text {nd }}, 3^{\text {rd }}$ and $4^{\text {th }}$ systems were recognised. The main process of grain transport within these forms was saltation. The ravines on the eastern slope of the Serteyka valley were most likely created in the periglacial period, while the gullies on the western side of the valley developed in the early modern period.
\end{abstract}

Key words: slope processes, deluvia, denudation valleys, erosion cuts, sediment lithodynamics, Late Weichselian, Holocene, Little Ice Age

\section{Introduction}

In the present-day valley of the Serteyka River, since the 1960s, during drainage works and later during archaeological research, a number of archaeological sites dating from the late Palaeolithic to the modern period have been discovered. The most interesting are globally unique Neolithic piledwelling settlements (e.g. Kul'kova et al. 2001, 2015; Mazurkievich et al. 2009a, b, 2012; Kittel et al. 2020, 2001; Wieckowska-Lüth et al. 2021). The Serteya region is important in research on the neolithisation of Eastern Europe because some of the earliest ceramics have been found there (Kul'kova et al. 2015). For many years, the lower section of the Serteyka valley has been the subject of not only intensive archaeological research, but also palaeo-environmental research (e.g. Mazurkievich et al. 2009a, b, 2012; Piech et al. 2018, 2020; Kittel et al. 2018, 2020, 2021; Mroczkowska et al. 2021a, b; Wieckowska-Lüth et al. 2021; Ginter et al. under review). The examination of cuts and fans was supposed to revise the hypothe- sis that the activities of Neolithic people shaped the slopes of the Serteyka River valley. Slope sediments from this region are interesting because of the possibility of them recording changes in environmental conditions taking place on the plateau.

Slope sediments constitute a specific geoarchive recording numerous changes in erosion and accumulation processes that are reflected in the structural and textural features of sediments. Their recognition is extremely important in the context of environmental reconstruction (Smolska 2005; Twardy 2008; Dotterweich et al. 2012; Kittel 2014; Piech et al. 2018; Szwarczewski et al. 2020).

The development of gullies and denudation valleys is influenced by many factors, both natural and anthropogenic. The natural factors are connected to one another. Less dense and fine sediments are more easily eroded. An additional factor "facilitating" erosion is steep slopes. Another factor is deforestation and the conversion of forests to arable lands; this deprives the surface of the earth of "protection", thereby intensifying slope processes. Then, there is a strong erosion of the slopes leading to the formation of, among other things,

\footnotetext{
${ }^{1}$ University of Lodz, Faculty of Geographical Sciences, Department of Geology and Geomorphology, St. Narutowicza 88, 90-139 Łódź; e-mail: wiktor.piech@edu.uni.lodz.pl, ORCID: 0000- 0001-5068-1631
} 
furrows, cuts, and covers of slope deposits. Extreme phenomena, e.g. heavy rains, cause a sudden intensification of erosion and accumulation processes, especially on slopes without forest cover (Teisseyre 1994; Poesen et al. 2003; Smolska 2005; Dotterweich 2008; Rodzik et al. 2008; Twardy 2008; Vanmaercke et al. 2016).

Various environmental changes, geomorphological processes (e.g. regression of ice cover, fluvial and slope activity), climatic fluctuations (e.g. changes in rainfall), vegetation or water conditions influence the formation and development of gullies (Table 1) (Klatkowa 1965; Twardy 1995,
2008, 2017; Starkel 2005; Valentin et al. 2005; Panin et al. 2009, 2011; Dreibrodt et al. 2010; Paluszkiewicz 2011; Jaworski 2018; Piech et al. 2018; Karasiewicz et al. 2019; Ginter et al. 2020, under review). On the other hand, the anthropogenic factor is human activity in its broader understanding, e.g. deforestation, agricultural activity, the causing of fires (Twardy 1995, 2008; Smolska 2005; Sidorchuk et al. 2006; Dotterweich 2008; Rodzik et al. 2008, 2015; Dotterweich et al. 2012; Golosov et al. 2017; Poesen 2018; Piech et al. 2018, 2020; Ginter et al. under review).

Table 1

Processes, conditions and effects on the slopes

\begin{tabular}{|c|c|c|c|}
\hline $\begin{array}{l}\text { Morphological } \\
\text { process }\end{array}$ & $\begin{array}{l}\text { Environmental } \\
\text { conditions }\end{array}$ & $\begin{array}{l}\text { Geomorphological } \\
\text { effects }\end{array}$ & Sample literature \\
\hline $\begin{array}{l}\text { slopewash, rain- } \\
\text { wash, surface } \\
\text { flow, creep flow, } \\
\text { mud flow }\end{array}$ & $\begin{array}{l}\text { rains of varying } \\
\text { intensity; plowing } \\
\text { method and type } \\
\text { of cultivation; } \\
\text { slope surface made } \\
\text { of fine material; } \\
\text { snow thawing }\end{array}$ & $\begin{array}{l}\text { slope sediment co- } \\
\text { vers in individual } \\
\text { slope zones; for- } \\
\text { mation of accumu- } \\
\text { lative fans }\end{array}$ & $\begin{array}{l}\text { Sinkiewicz 1989, 1998; Teisseyre 1994; } \\
\text { Stochlak 1996; Smolska 2003, 2005, 2008; } \\
\text { Twardy 1995, 2000, 2008; Belyaev et al. } \\
\text { 2005; Mycielska-Dowgiało, Ludwikowska- } \\
\text { Kędzia 2011; Kittel 2014, 2016; Ratajczak- } \\
\text { Szczerba, Paluszkiewicz 2015; Piech et al. } \\
\text { 2018; Karasiewicz et al. 2019; Szwar- } \\
\text { czewski et al. 2020; Ginter et al. under re- } \\
\text { view }\end{array}$ \\
\hline $\begin{array}{l}\text { soil erosion, linear } \\
\text { erosion, slope ero- } \\
\text { sion, rill wash, } \\
\text { splash erosion, } \\
\text { piping }\end{array}$ & $\begin{array}{l}\text { intense rains; lack } \\
\text { of a dense plant } \\
\text { cover; high slope; } \\
\text { slope surface made } \\
\text { of fine material }\end{array}$ & $\begin{array}{l}\text { formation of small } \\
\text { size cuts (rills); } \\
\text { slope denudation }\end{array}$ & $\begin{array}{l}\text { Sinkiewicz 1989, 1998; Teisseyre 1994; } \\
\text { Stochlak 1996; Smolska 2003, 2005, 2007, } \\
\text { 2008; Twardy 1995, 2000, 2008; Sidorchuk } \\
\text { et al. 2006; Dotterwiech 2008; Dreibrodt } \text { et } \\
\text { al. 2010; Dotterweich } \text { et al. 2012; Kittel } \\
\text { 2014, 2016; Majewski 2014; Ratajczak- } \\
\text { Szczerba, Paluszkiewicz 2015; Jaworski } \\
\text { 2018; Piech et al. 2018; Poesen 2018; } \\
\text { Karasiewicz et al. 2019; Szwarczewski et al. } \\
\text { 2020; Ginter } \text { et al. under review }\end{array}$ \\
\hline $\begin{array}{l}\text { rill erosion, } \\
\text { ephemeral gully } \\
\text { erosion, gully ero- } \\
\text { sion, road gully } \\
\text { erosion }\end{array}$ & $\begin{array}{l}\text { lack of a dense } \\
\text { plant cover; pro- } \\
\text { longed heavy } \\
\text { rains; the occur- } \\
\text { rence of extreme } \\
\text { phenomena; strong } \\
\text { deforestation of } \\
\text { the upland area }\end{array}$ & $\begin{array}{l}\text { formation of large } \\
\text { erosive cuts and } \\
\text { gullies }\end{array}$ & $\begin{array}{l}\text { Klatkowa 1965, 1989; Poesen et al. 2003; } \\
\text { Belyaev et al. 2005, 2020; Smolska 2005, } \\
\text { 2007; Twardy 1995, 2005, 2008; Valentin et } \\
\text { al. 2005; Panin et al. 2009, 2011; Dreibrodt } \\
\text { et al. 2010; Paluszkiewicz 2011, 2014; } \\
\text { Tylman 2011; Dotterweich et al. 2012; } \\
\text { Majewski 2014; Zgłobicki et al. 2014; } \\
\text { Rodzik et al. 2015; Vanmaerke } \text { et al. 2016; } \\
\text { Golosov et al. 2017; Jaworski 2018; Piech et } \\
\text { al. 2018; Karasiewicz et al. 2019; Majewski, } \\
\text { Paluszkiewicz 2019; Piech et al. 2020 }\end{array}$ \\
\hline
\end{tabular}

There are many processes affecting the morphology of gullies and their accumulative fans (Table 1). In gullies or erosion-denudation valleys, periods of increased erosion and accumulation alternated. These forms constitute an important part of the shaping relief processes.
The aim of the study is to analyse the textural features of accumulative fan sediments, and on their basis to determine the erosion, transport, deposition and redeposition processes, as well as their geomorphological characteristics. 


\section{Research area}

The study area is located in the valley of the lower Serteyka River, which is on the Russian Plain in western Russia, on the border of the Pskov, Tver and Smolensk oblasts. This area was within the range of the last Weichselian ice sheet (Valdai ice sheet) (Fig. 1). The Serteyka River uses a subglacial channel created during the last ice age. After the deglaciation, blocks of dead ice remained in the tunnel valley, which, as they melted, gave rise to lakes. In the Holocene, these were drained, and a fluvial system was developed (Kittel et al. 2018; Piech et al. 2018).

On the western side of the Serteyka River valley, the upland is formed mostly of fluvioglacial sands. Further to the west and south-east there are several clay horizons within fluvioglacial deposits (Piech et al. 2020). In turn, the eastern plateau is formed primarily of glacial till. Within the palaeolake basins there are kames and kame terraces build by sands and silts. These forms are partially covered by gyttja and fluvial overbank deposits. The beginning of lacustrine sediment accumulation was in the Late Weichselian (Kittel et al. 2018). In the lower parts of the slopes of the subglacial channel, strips of slope sediments and gullies with accumulative fans have developed (Piech et al. 2018, 2020) (Fig. 2).

Several in-depth palaeogeographic studies have been carried out in the Serteya region, but the focus has been primarily on biogenic sediments (Fig. 3) (e.g. Kittel et al. 2018, 2020, 2021; Tarasov et al. 2019; Łuców et al. 2020; Mroczkowska et al. 2021a, b; Wieckowska-Lüth et al. 2021).

Currently, erosion and accumulation processes are observed on the slopes of the studied part of Serteyka River valley (former tunnel valley) and within the erosion cuts. The upland is mostly deforested, and periodic farming is carried out here, although in recent seasons the fields have turned to fallow land, while the slopes, erosion cuts, accumulative fans and the valley floor are wasteland with small clusters of trees (Piech et al. 2020).

\section{Methods}

The sedimentological research covered seven erosion cuts (gullies) and their accumulative fans that were formed on the slopes and the Serteyka River valley floor. Gullies on the western side of the Serteyka River valley are marked with the letters A, B,
$\mathrm{C}$, while gullies on the eastern side of the valley are marked with the letters D, E, F (Fig. 2).

The field work included detailed geological mapping of gullies and their accumulative fans, which was performed using the Eijkelkamp geological hand auger equipped with a gouge auger. The sediments were analysed with an accuracy of $1 \mathrm{~cm}$. The distance between the drillings was $5 \mathrm{~m}$ for fans of gullies A and B and from 5 to $30 \mathrm{~m}$ for the other gullies' fans. The samples for the study of gully A were taken from two geological outcrops. The first lay in the central zone, the second in the distal zone. Samples with a volume of approx. $1 \mathrm{~cm}^{3}$ were taken with an accuracy of $1-3 \mathrm{~cm}$ from macroscopically distinguishable layers (Piech et al. 2018). For other fans, samples for laboratory tests were taken from drillings from each macroscopically distinguishable layer.

Laboratory work included grain-size analysis by laser diffraction using the Malvern MasterSizer 3000 analyser with a water attachment, available at the laboratory of the Institute of Geography of the Pedagogical University in Krakow. The laser diffraction method was used for fractions below $2.0 \mathrm{~mm}$, and, for the coarser fraction, the sieve method was used (carried out in the laboratory of Faculty of Geographical Sciences University of Lodz). Then the sedimentological indices were calculated according to Folk and Ward (1957): mean grain diameter $\left(\mathrm{M}_{\mathrm{Z}}\right)$, standard deviation (sorting $\left.\sigma_{\mathrm{I}}\right)$, skewness $\left(\mathrm{Sk}_{\mathrm{I}}\right)$, and kurtosis $\left(\mathrm{K}_{\mathrm{G}}\right)$. The calculations were made using the Gradistat 5.11 program (Blott, Pye 2001). The SPAN index was also calculated using the formula $\left[\left(\mathrm{D}_{90}-\mathrm{D}_{10}\right) / \mathrm{D}_{50}\right]($ after Foster 1991; Warrier et al. 2016).

\section{Methods for the analysis of lithodynamics of slope processes}

The relations between mean grain diameter and sorting were used to analyse the dynamics of slope processes and the conditions of sediment deposition (see Folk, Ward 1957). The arrangement of these relations is important in determining the dynamics of transport and the processes of material accumulation within a specific environment (Mycielska-Dowgiałło 1995). So far, four $\mathrm{M}_{\mathrm{Z} \text {-versus- }}$ $\sigma_{\mathrm{I}}$ systems have been defined (Mycielska-Dowgiałło 1995; Mycielska-Dowgiałło, LudwikowskaKędzia 2011), i.e.:

- $1^{\text {st }}$ system (as average grain diameter increases, sorting values decrease simultaneously): characteristic of channel deposits, 


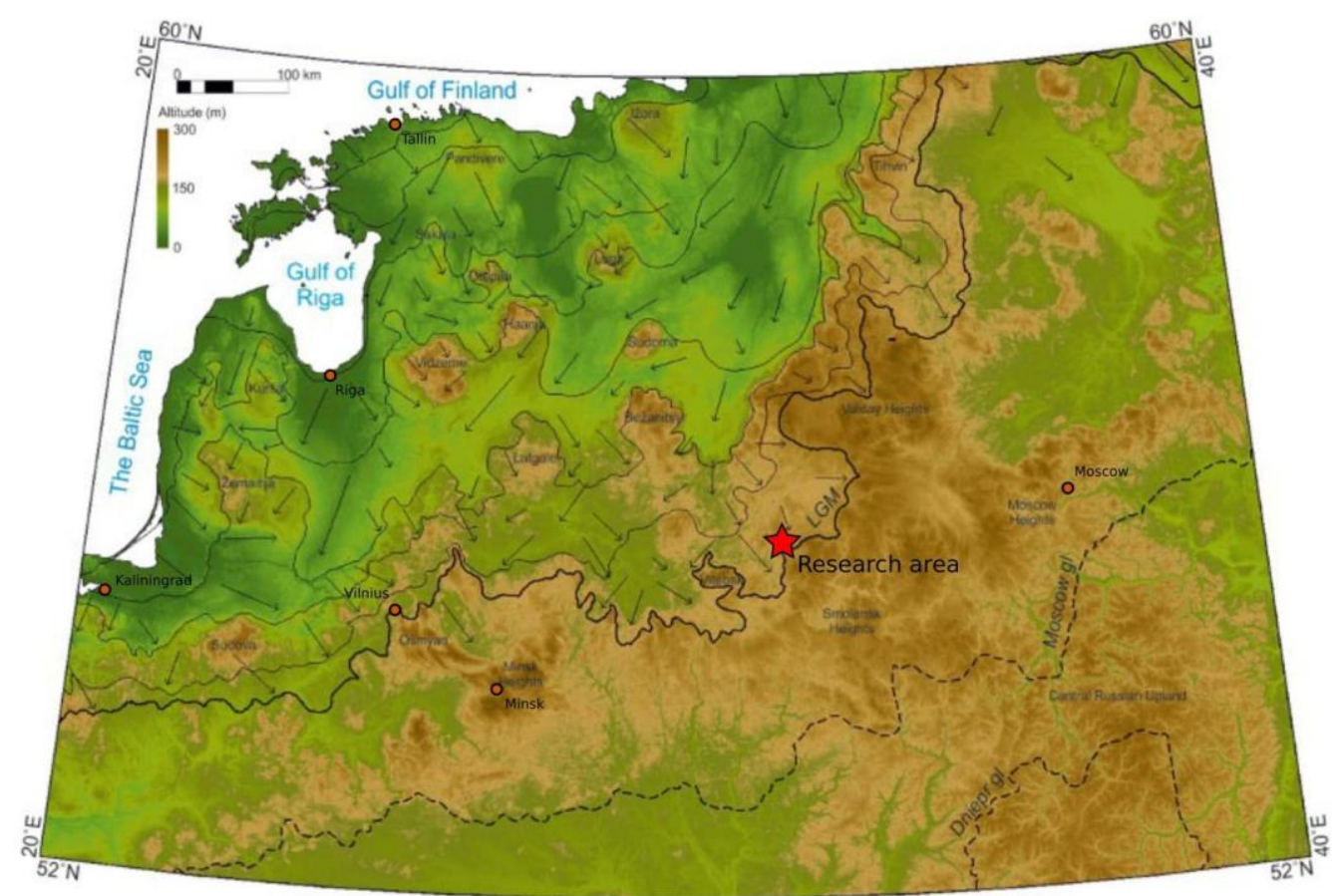

Fig. 1. Location of research area (Gorlach et al. 2015)

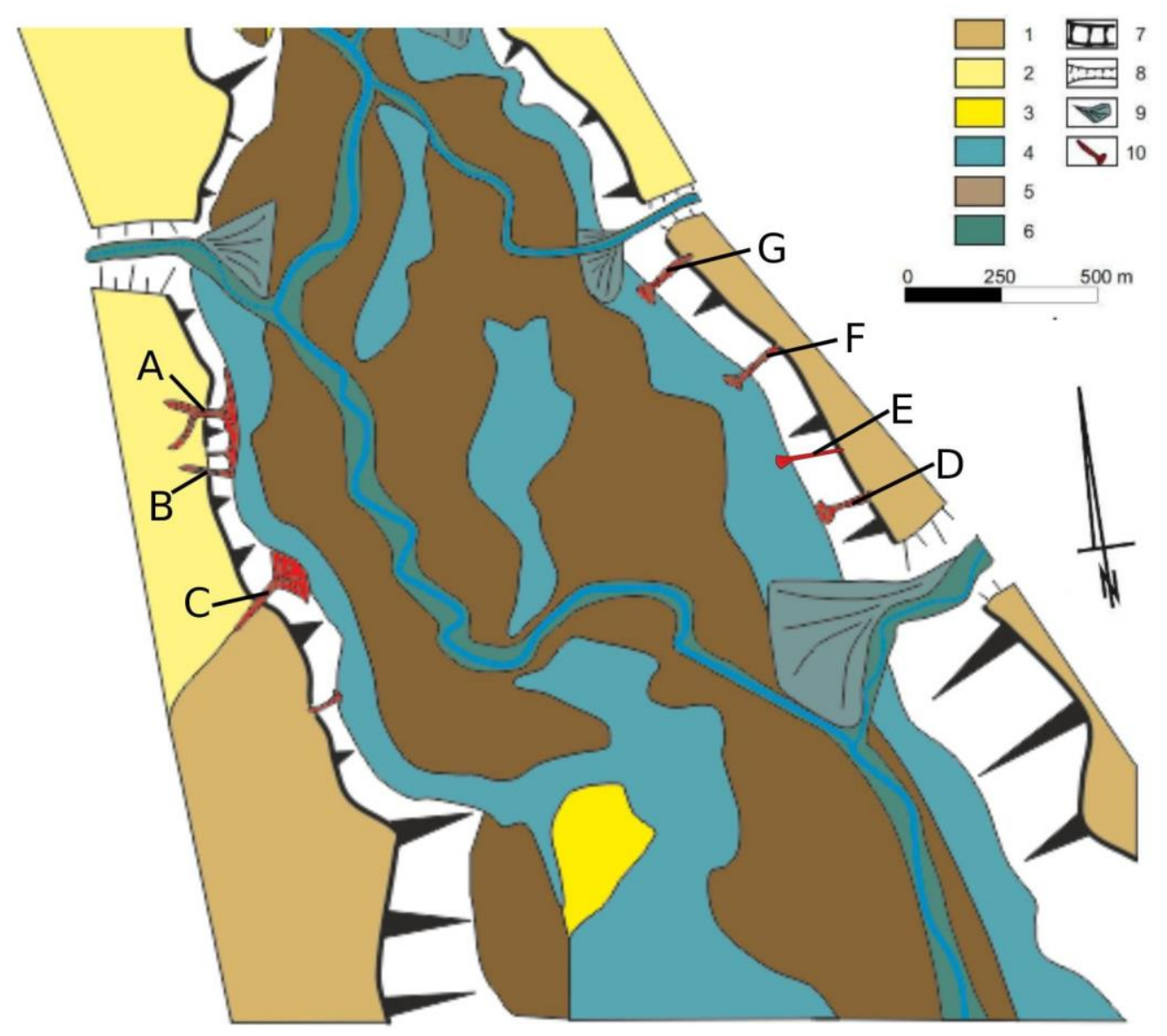

Fig. 2. Geomorphological sketch of studied fragment of Serteyka River valley after Kittel et al. (2018)

1 - moraine plateau; 2 - glaciofluvial plain; 3 - crevasse fills; 4 - kames and kame terraces; 5 - biogenic plains; 6 - flood plain; 7 - subglacial channel; 8 - valley slopes; 9 - alluvial fans; 10 - gullies, denudational valleys and their accumulative fans (A, B, C, D, E, F, G) 

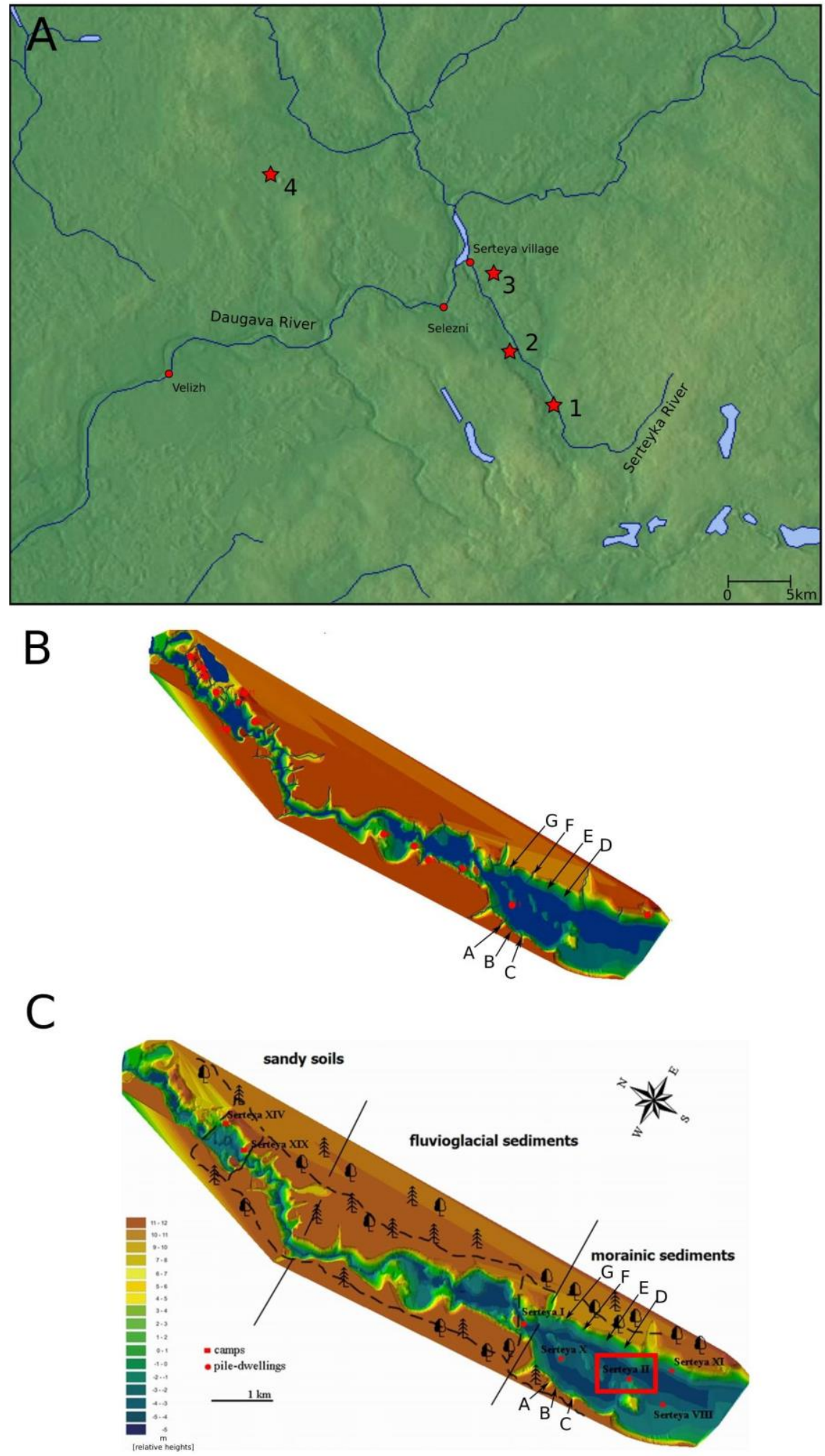

Fig. 3. Location of palaeogeographic research in Serteya region (A) and archaeological and palaeogeographic research in Serteyka River valley $(\mathrm{B}, \mathrm{C})$

A. 1 - Kittel et al. (2018, 2020a, b); Mroczkowska et. al. (2021a); Piech et al. (2018, 2020); 2 - Tarasov et al. (2019); 3 - Mroczkowska et al. (2021b); 4 - Łuców et al. (2020)

B. Early Neolithic sites $c a$ 6500-5000 cal. BC (Kul'kova et al. 2015); letters indicate tested gullies denudational valleys and their accumulative fans

C. Mid- and late Neolithic sites $c a$ 4500-1800 cal. BC (Kul'kova et al. 2015); letters indicate tested gullies, denudational valleys and their accumulative fans; rectangle indicates site of in-depth palaeogeographic research (e.g. Kittel et al. 2018, 2020a, b; Mroczkowska et. al. 2021a) 
- $2^{\text {nd }}$ system (as average grain diameter decreases, sorting values decrease): refers to overbank deposits, aeolian deposits of hot deserts, wash-out deposits, fluvial channel lag,

- $3^{\text {rd }}$ system (mean grain diameter values vary, while sort values are constant): typical of aeolian deposits of the moderate climate zone, overbank-pool deposits,

- $4^{\text {th }}$ system (mean grain diameter values are similar, but sorting values differ) typical of slope sediments formed by splashing of rain drops.

Another method for determining the type of sedimentation and the specification of morphodynamic processes is the analysis of the particle-size distribution frequency curves, which illustrate the share of grains of certain diameters each sediment (in a given sample). By determining the modes that occur in them, it is possible to estimate the strength of the transporting centre and the duration of lithodynamic processes, and to distinguish the source material for the deposited sediments (MycielskaDowgiałło 1995; Racinkowski et al. 2001; Mycielska-Dowgiałło, Ludwikowska-Kędzia 2011). It should be noted that the features of slope sediments in terms of the distribution of $\mathrm{M}_{\mathrm{Z}}$-versus- $\sigma_{\mathrm{I}}$ corresponds to the features of overbank alluvia (Smolska 2005; Twardy 2008). When distinguishing types of sediments, other analysis can be supported, e.g. the content of organic matter, the content of lithophilic elements, as well as a structural analysis (see Kittel et al. 2020).

It should be emphasised that when interpreting the $\mathrm{M}_{\mathrm{Z}}$-versus- $\sigma_{\mathrm{I}}$ relations with respect to systems, one should take into account environmental changes over time. These analyses should be preceded by the interpretation of the curves of sedimentological indicators, in which fluctuations, simultaneous decreases/increases in value, or the presence of plateau indicate a change in erosion and accumulation processes and therefore an environmental change. After dividing the profile and separating fragments with different tendencies, one can apply the interpretation in relation to individual systems. Then we get a full picture of changes in the dynamics of the sedimentological environment. Therefore, during the research, the problem of determining all the features (different systems) that change with depth was found.

Another method is the analysis of Visher curves (Visher 1969). Based on the course of the curves (analysis of sections A, B, C), the method of grain transport is analysed: rolling, saltation or transport in suspension (Visher 1969; MycielskaDowgiałło 1995; Szmańda 2010, 2011; Mycielska-Dowgiałło, Ludwikowska-Kędzia 2011).
Another method for analysing the depositional conditions is the analysis of the relationship between first percentile and grain median in the Passega C/M diagram. In this diagram, we can distinguish several segments of transport fields, i.e. $\mathrm{N}-\mathrm{O}, \mathrm{O}-\mathrm{P}, \mathrm{P}-\mathrm{Q}, \mathrm{Q}-\mathrm{R}, \mathrm{R}-\mathrm{S}$, which explain the conditions of material transport and deposition, e.g. graded suspension (Q-R segment). The C/M Passega diagram also shows the fields of depositional environment types (from I to VIII) (Passega 1964; Passega, Byramjee 1969; Racinkowski et al. 2001; Szmańda 2010, 2011). It should also be noted that the results of interpretations based on the Passega C/M diagram may not agree with the interpretation of the cumulative grain-size distribution curve (Szmańda 2010). SPAN index is another factor that determines the dynamics of the environment. The 10th, 50th and 90th percentiles are used. SPAN index is a dimensionless sorting index (Foster 1991; Warrier et al. 2016).

Individual methods with an in-depth description and analysis of the results are presented in: Udden (1914); Wentworth (1922); Krumbein (1934); Folk, Ward (1957); Passega (1964); Passega, Byramjee (1969); Visher (1969); MycielskaDowgiałło (1995); Racinkowski et al. (2001); Szmańda (2010, 2011) and Mycielska-Dowgiałło, Ludwikowska-Kędzia (2011).

The above-mentioned methods have been successfully implemented to analyse the erosion and accumulation processes of slope sediments (e.g. Twardy 1995, 2000, 2003; 2005, 2008; Stochlak 1996; Smolska 2003; 2005, 2007, 2008; Kittel 2014, 2016; Majewski 2014, 2017; Paluszkiewicz 2014; Ratajczak-Szczerba, Paluszkiewicz 2015; Piech et al. 2018; Karasiewicz et al. 2019; Ginter et al. under review).

\section{Results and Interpretation}

Due to the complexity of the situation in individual geological profiles, the author proposes to introduce extended system records relating to the $\mathrm{M}_{\mathrm{Z}}$-versus- $\sigma_{\mathrm{I}}$ relations. The proposals of entries are intended to make the description more detailed.

1) Where the $M_{Z}$-versus- $\sigma_{I}$ relation exhibits a set of points that matches the features of two different systems (after Mycielska-Dowgiałło, Ludwikowska-Kędzia 2011), the following notation can be used: "x/x system"; for example:" $3^{\text {rd }} / 4^{\text {th }}$ system".

2) Where the $M_{z}$-versus- $\sigma_{I}$ relation exhibits many systems (each at a different depth), the notation " $\mathrm{x}(\mathrm{x}, \mathrm{x})$ system" should be used; for example " $1^{\text {st }}\left(3^{\text {rd }}, 4^{\text {th }}\right)$ system" or “ $2^{\text {nd }}\left(2^{\text {nd }}, 1^{\text {st }}, 4^{\text {th }}\right)$ system". In 
this notation, the first number is the system recognised for the entire population in the $\mathrm{M}_{\mathrm{Z}}$-versus- $\sigma_{\mathrm{I}}$ relationship diagram, whereas the numbers in parentheses represent the systems recognised for the sediments of individual sections (units, segments) of the profile (i.e. from individual depths). The unity (segments) of the profile can be distinguished based on, among other things, the curves of sedimentological indicators. The order of the systems in the proposed notation depends on the depth of the recognised units. Thus, the first system within the parentheses records the bottom of the geological profile.

\section{Gully A (western part of the valley)}

This gully is cut into the upland to a length of about $210 \mathrm{~m}$ and a depth of approx. $7 \mathrm{~m}$, and at its widest point it is $12 \mathrm{~m}$ wide. In the mouth section has a U-shaped cross profile. The inclination of the slopes is up to $52^{\circ}$. In the upper parts of the gully, it adopts a V-shaped profile (Piech et al. 2018, 2020).

The fan sediments developed at the mouth of gully A covered a coarse detritus gyttja in the central and distal zone of the form. The top part of organic deposits was dated to the $2^{\text {nd }}$ half of the $17^{\text {th }}$ century AD (Piech et al. 2018). The inorganic deposits of the fan have been divided into a few sedimentological units: lower deluvia, proluvia, middle deluvia, upper deluvia and tillage diamicton. The lower deluvia are fine, slightly silty sands with numerous laminations of silt. This series is light brown in colour. The proluvia are coarse sands with numerous clay balls. Above, there are brown fine sands, with an admixture of medium sand (middle deluvia) in some places. The sediments of this series have a massive structure. The upper deluvia are fine, slightly silty, sub-horizontal layered sands. The top part of the fan's deposits is built of tillage diamicton (Piech et al. 2018; Ginter et al. under review).

In the distal zone, the coarse-detritus gyttja is covered with fine silty sands; above that, the content of the silty fraction increases, and is covered with overbank alluvia.

In the central part of the fan, the values of sedimentological indicators fluctuate strongly for the lower and upper deluvia, while relatively constant values are recorded for the middle deluvia unit (Fig. 4A). The sediments in this part of the fan are characterised by poor or moderate sorting, where the grain-size ranges from 3 to $4 \mathrm{phi}$. It is noticeable that the skewness values increase towards the top of the profile. The proluvia are characterised by the lowest $\mathrm{M}_{Z}$ values and the poorest sorting (Piech et al. 2018). The particle-size distribution frequency curves for these sediments are usually unimodal, except for the proluvia, which are characterised by a polymodal curves (Fig. 4D). The main transport process was saltation for deluvial sediments, and traction for proluvia (Piech et al. 2018). In the diagram of the $\mathrm{M}_{\mathrm{Z}}$-versus- $\sigma_{\mathrm{I}}$ relation, deluvial sediments are arranged in the $2^{\text {nd }}$ system, while the proluvia take the $1^{\text {st }}$ system, indicating the current environment (Fig. 4B). However, in the lower deluvia the $2^{\text {nd }}$ system can be distinguished, for the middle deluvium it is the $4^{\text {th }}$ system and for the upper deluvia it is the $2^{\text {nd }}$ system (after Mycielska-Dowgiałło 1995; Mycielska-Dowgiałło, Ludwikowska-Kędzia 2011). The code for the entire profile is $2^{\text {nd }}\left(2^{\text {nd }}, 4^{\text {th }}, 2^{\text {nd }}\right)$ system can be used. Deluvia have unimodal particle-size distribution curves and the saltation process dominates in the transport of grains. All deluvia are in the Passega C/M diagram in fields $\mathrm{V}$ (gradation suspension transported under conditions of moderate turbulence) and VI/VII (gradation suspension transported under low turbulence conditions, characterised by different particle size) in Q-R segment (graded suspension), while proluvia are in fields I and II and P-Q segment (graded suspension with some grain transported by rolling) and in O-P segment (rolling with some grain transported in suspension) (Fig. 4C) (after Passega 1964; Passega, Byramjee1969). A lot of samples are also found in the Tc zone, which is interpreted as characteristic of sediments formed in conditions of density runoff (see Szmańda 2011). It is noticeable that in the lower deluvium there are usually constant values of the SPAN index. The exception is the depth of $138 \mathrm{~cm}$ b.g.l., where the value is several times greater. On the other hand, in the middle and upper deluvium, numerous fluctuations in the value of this index are noticeable, from 0.5 to 1.2 .

In the distal zone of the fan, the highest values of $\mathrm{M}_{\mathrm{z}}$ above 5 phi are visible, while grains with the grain size of 3-4 phi dominate. Sorting is poor or moderate. For deluvial sediments, the particle-size distribution frequency curves are unimodal. Analysing the cumulative grain-size distribution curves (Fig. 5E), the conclusion was obtained that saltation dominated in the transport process (see Visher 1969; Mycielska-Dowgiałło, Ludwikowska-Kędzia 2011; Szmańda 2011).The fan deposits from the distal zone assume the $2^{\text {nd }}$ system. The particle-size distribution curves are usually unimodal. As with sediments from the central zone, so too here, saltation dominates in the transport of grains. In the Passega $\mathrm{C} / \mathrm{M}$ diagram, the samples are located mainly in fields V and VI/VII (Fig. 5C) 
and in Q-R segment (graded suspension) and in the Tc zone (after Passega 1964; Passega, Byramjee 1969; Szmańda 2011). The SPAN index values are constant and hover around 3.2. The values of this index are almost double higher the values for the central zone.

\section{Gully B (western part of the valley)}

This gully hangs $2 \mathrm{~m}$ above the valley floor. It is cut into the upland to a depth of $2 \mathrm{~m}$, and to a length of approx. $70 \mathrm{~m}$, with a maximum width of $10 \mathrm{~m}$. The slopes inclinations of the ravine range from $26^{\circ}$ to $52^{\circ}$ (Piech et al. 2020).

In the central zone, the sediments of the fan covered coarse detritus gyttja. The bottom of the fan sediments is made of fine, light-brown sands. There is fine gravel in some places above it and the colour changes to light grey and then back to light brown. The sediment thickness of the fan is approx. $175 \mathrm{~cm}$.

From a depth of 172 to $140 \mathrm{~cm}$ b.g.l., there is a distinct change in mean particle diameter value, along with poor sorting. Further, from 140 to 110 $\mathrm{cm}$ b.g.l. there is an increase the mean grain diameter and a deterioration in sorting (Fig. 6A). This proves a change in the transport conditions and a decrease in the dynamics (variability) of the environment. Positive skewness values were recorded in all samples. From the depth of $102 \mathrm{~cm}$ to $20 \mathrm{~cm}$ b.g.l., environmental conditions can be postulated. The sediments are moderately sorted, which proves the relative stability of the transport dynamics. For the entire set of points $(172-20 \mathrm{~cm}$ b.g.l.) in the relation $\mathrm{M}_{\mathrm{Z}}$-versus- $\sigma_{\mathrm{I}}$, a second system can be defined after Mycielska-Dowgiałło and Ludwikowska-Kędzia (2011), characteristic of, among others, slopewash deposits. On the other hand, three populations can be distinguished here. The $2^{\text {nd }}$ system can be determined for the first and second populations, while population 3 (samples at depths $170-171$ and $150-140 \mathrm{~cm}$ b.g.l.) is characterised by the $4^{\text {th }}$ system, which refers to slope sediments formed by splashing of rain drops (after Mycielska-Dowgiałło, Ludwikowska-Kędzia 2011). From the particle-size distribution frequency curves, it can be concluded that, firstly, grains with a size of 2-3 phi were accumulated, the curves are leptokurtic, then the strength of the transporting medium changed, as a result of which finer grains in the range of 2.5-4 phi were deposited. Further, conditions stabilised and grains with a size of 3-4 phi were mostly accumulated.
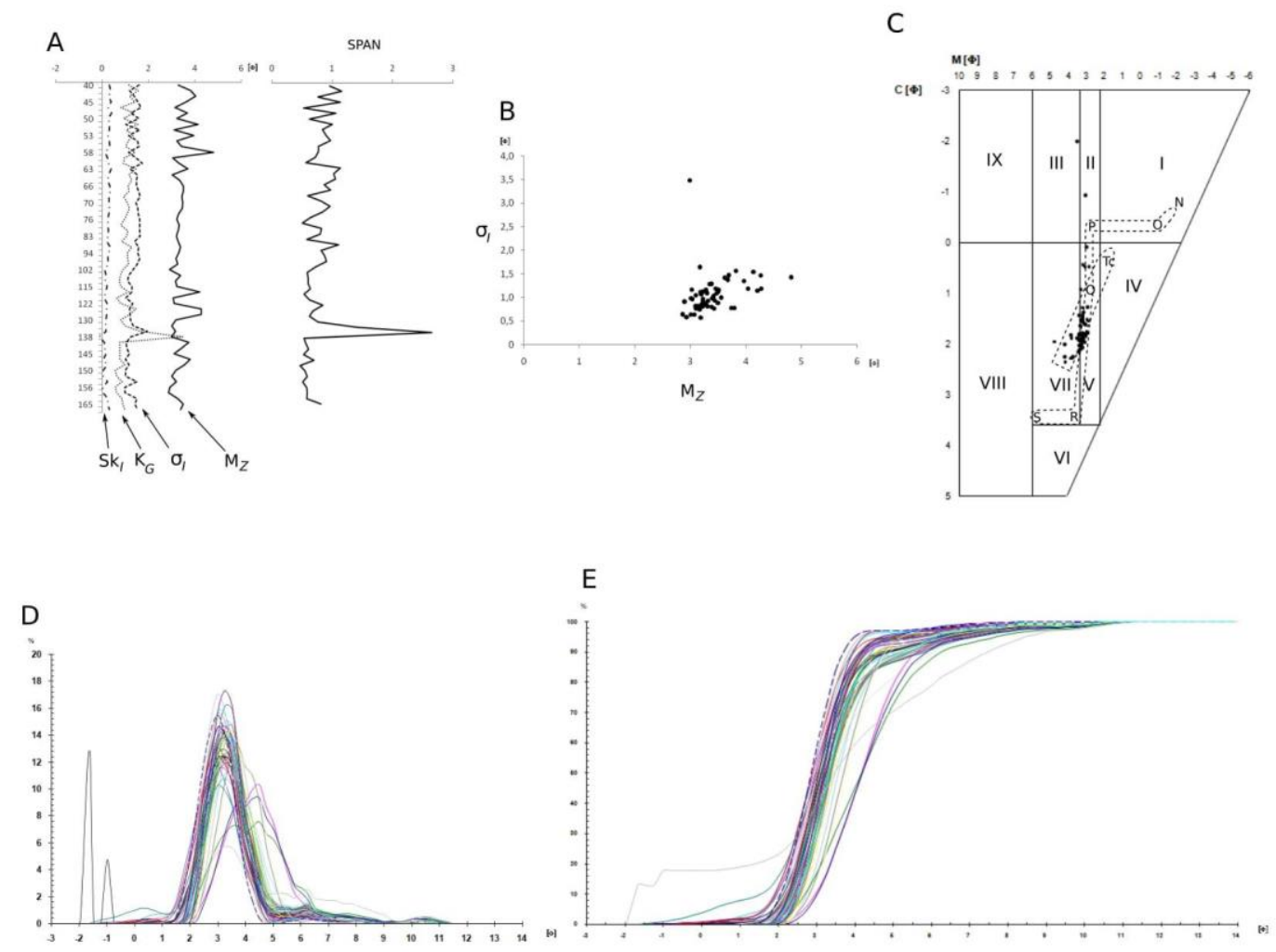

Fig. 4. Textural features of central zone sediments of gully A

A - sedimentological indicator curves: $\mathrm{M}_{\mathrm{Z}}$ - mean grain diameter, $\sigma_{\mathrm{I}}-$ sorting, $\mathrm{K}_{\mathrm{G}}-$ kurtosis, $\mathrm{Sk}_{\mathrm{I}}-$ skewness; $\mathrm{B}-$ relation $\mathrm{Mz}_{\mathrm{Z}}$ versus $\sigma_{\mathrm{I}} ; \mathrm{C}$ - Passega C/M diagram; D - particle-size distribution frequency curves; $\mathrm{E}$ - cumulative grain-size distribution curves 


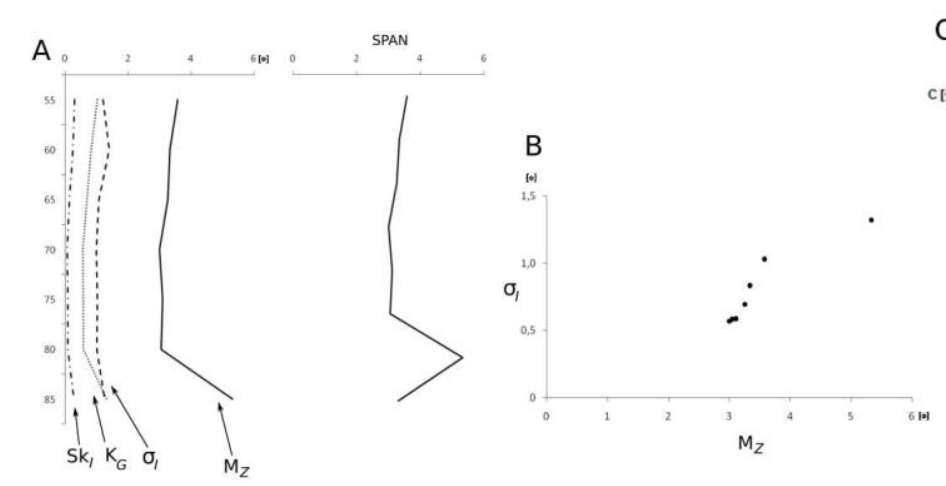

C
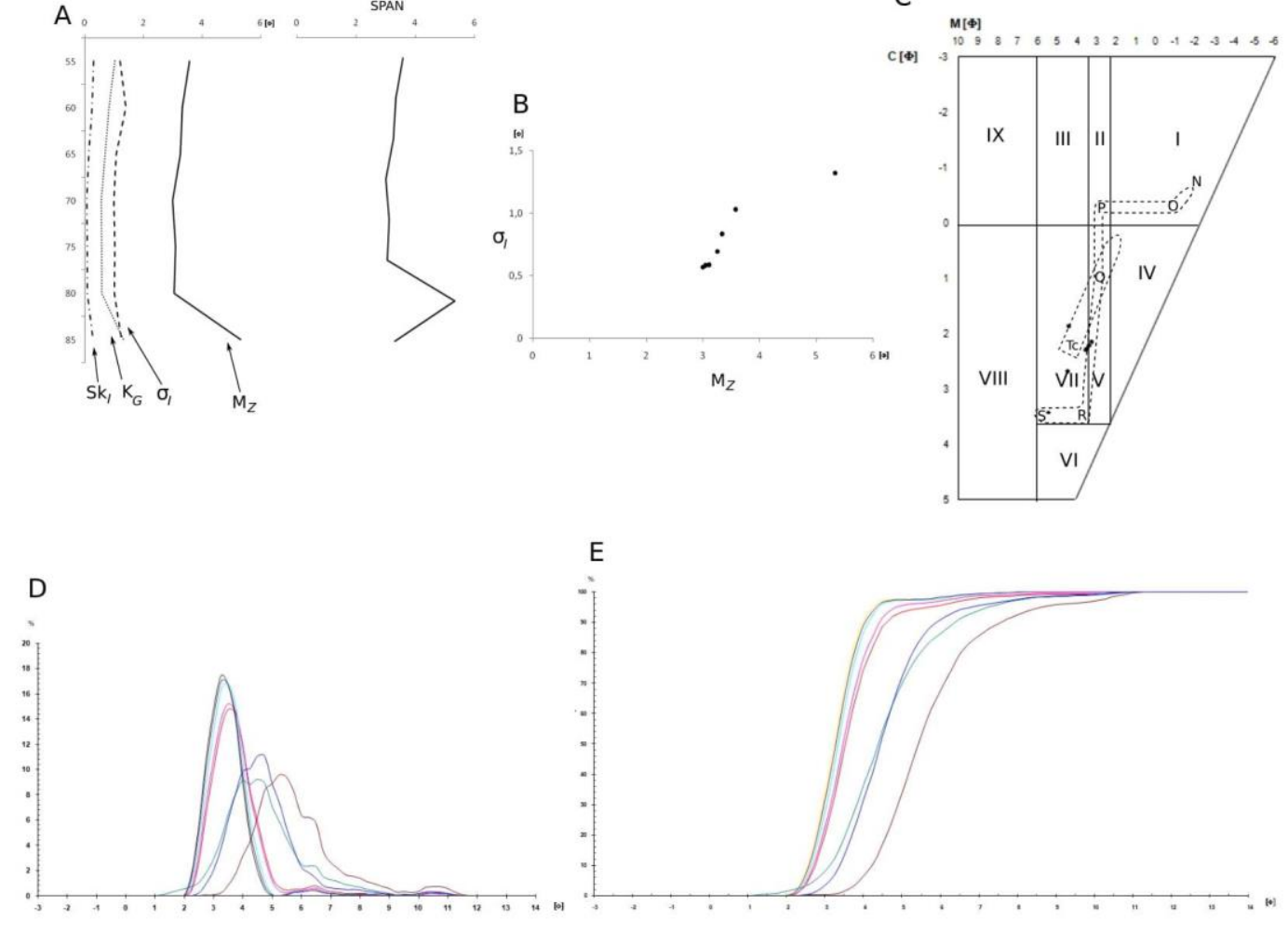

Fig. 5. Textural features of distal zone sediments of gully A explanations in Fig. 3
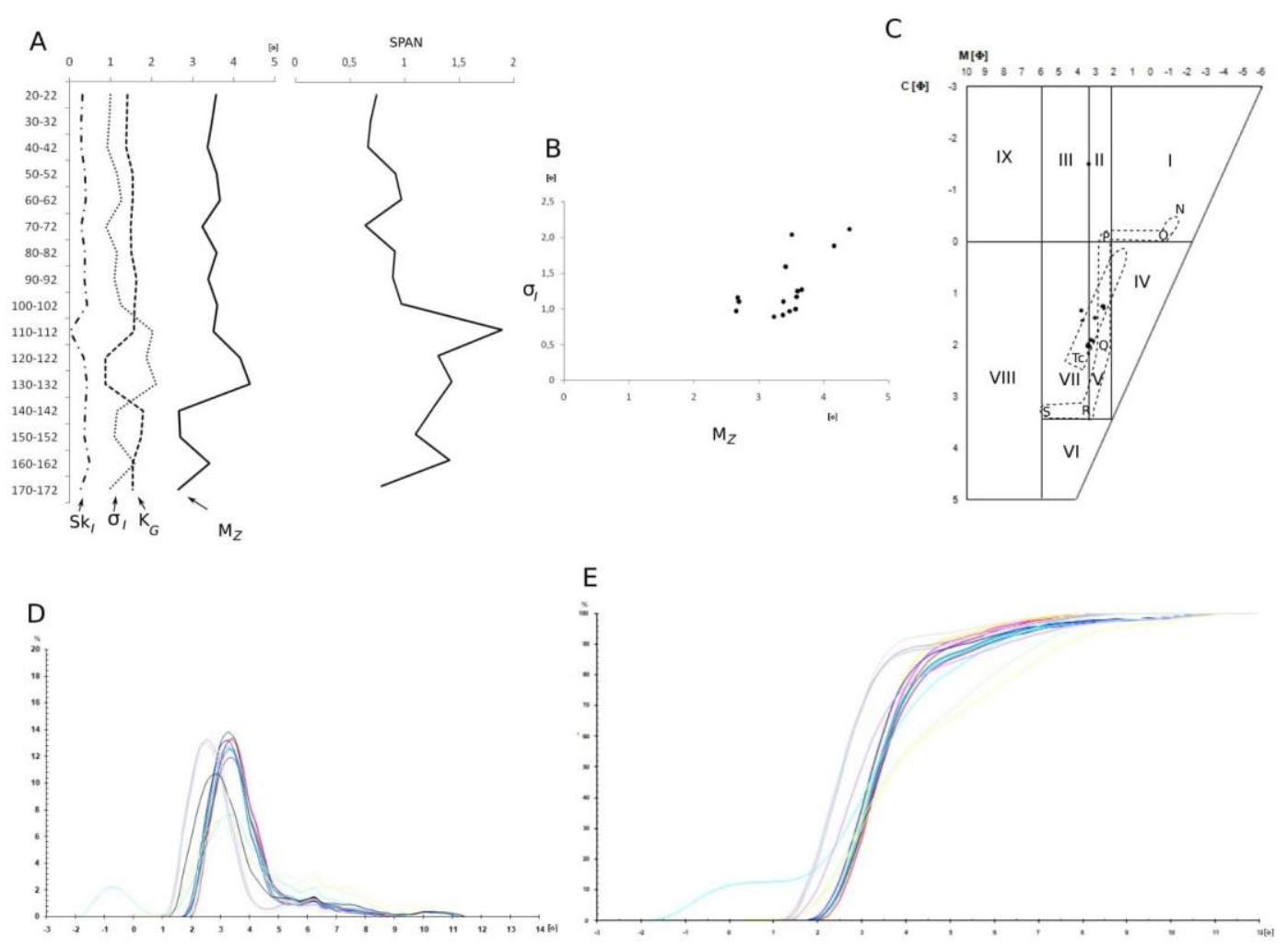

Fig. 6. Textural features of central zone sediments of gully B

explanations in Fig. 3 
In the Passega $\mathrm{C} / \mathrm{M}$ diagram, $50 \%$ of the samples are in field VI and VII (gradation suspension transported under low turbulence conditions, characterised by different particle size), $44 \%$ of the samples are in field V (gradation suspension transported under moderate turbulence conditions), and one sample (110-112 cm b.g.l.) is located in field III (traction deposition with a small proportion of suspension dominates here) (after Passega and Byramjee 1969). The samples are in the $P-Q$ segment (graded suspension with some grain transported by rolling) and in a Tc zone (density runoff) (Fig. 6C) (after Passega 1964). From a depth of 172 to $110 \mathrm{~cm}$ b.g.l. SPAN index values are higher (average value 0.82 ) than the values from the depth of 102-20 cm b.g.l. (mean value 1.31).

\section{Gully C (western part of the valley)}

The slopes of this gully are steep, in some places reaching $60^{\circ}$. The form is cut into the upland to a depth of $7 \mathrm{~m}$ and a length of about $80 \mathrm{~m}$ and a bottom width of up to $10 \mathrm{~m}$ in the mouth zone. There are numerous hanging ravines and smaller erosive cuts notes. At the bottom of the ravine, a 3-m-wide deepening can be seen that is connected with the side fan (STA profile).

In the proximal zone, the sediments of the fan lie directly on fluvioglacial sediments. At the bottom, the fan is built of silty fine, light-brown sands with individual small charcoals. Above, there are alternately silty fine sands, poorly laminated in places, and various sands. At particular depths, they vary in colour from light brown to light grey. At a depth of about $100 \mathrm{~cm}$ b.g.l. single charcoals also appear, while at a depth of approx. $50 \mathrm{~cm} \mathrm{b.g.l.}$ the number of charcoals increases.

In the central zone, too, the deposits of the fan cover fluvioglacial deposits. In this part the fan is made of fine silty sands, lightly laminated light brown. At depths from 292 to $272 \mathrm{~cm}$ and 252-225 $\mathrm{cm}$ b.g.l. there are fine, slightly silty grey sands with plant detritus. From a depth of 225 to $214 \mathrm{~cm}$ b.g.l. there are alternately fine silty sands and silts in colours ranging from grey to orange. Above, there are fine, poorly laminated sands and, in some places, various sands. The sediment thickness of the fan in the central zone is $300 \mathrm{~cm}$.

In the distal zone, fine and medium laminated sands dominate, with small fragments of wood and plant detritus in places. Charcoals have been documented at depths of 232-290, 211-197, 115-113, 103-93 and 39-32 cm b.g.l.

In the proximal zone, the deposits from a depth of 317-300 cm b.g.l. represent the sediment of the substrate. From the floor to the depth of $196 \mathrm{~cm}$ b.g.l., poor sorting is visible, and from this depth up to the top of the profile the sorting is very poor (Fig. 7A). Very large fluctuations are visible in the values of sedimentological indicators. This proves the variability of the force of dynamics of the grain-transporting force, and therefore testifies the relative instability of the depositional environment. This does not correspond to the data obtained from gullies $\mathrm{A}$ and $\mathrm{B}$, possibly because gully $\mathrm{C}$ is older. During the accumulation of this fan, different environmental conditions prevailed. At particular depths, there is a sudden decrease in the mean grain diameter and skewness, as well as a sudden deterioration in sorting. This testifies to the intense erosion processes that washed away the finer material and left the thicker, poorly sorted deposits. There are also places where the fluctuations in mean size diameter and sorting values are accompanied by uniform values of skewness. These are periods of relative balanced of the grain-transporting force, and they also indicate the stability of the immediate surroundings of gully C. Strong multimodality of the curves may indicate the deposition of aggregates connected with clay/silts. In the $\mathrm{M}_{\mathrm{Z}}$-versus- $\sigma_{\mathrm{I}}$ relation, two populations can be distinguished. The first population is associated with erosive processes, where there was a strong washing-out of grains and the delivery of poorly sorted material, while the second population determines the advantage of accumulation over erosion, although the point cloud is stretched, which may also indicate the relative instability of the depositional environment. For the entire profile, the $2^{\text {nd }}$ system can be recognised. Two sample populations can also be distinguished in the Passega C/M diagram. The first is located in fields I, II, III related to traction deposition with a small share of suspension. The samples are closest to $\mathrm{N}-\mathrm{O}$ segment (accumulated by rolling) and O-P (accumulated by rolling with some grain transported in suspension) (after Passega 1964). The second population of samples is in field V (gradation slurry transported under moderate turbulence), VI/VII (gradation suspension transported under low turbulence conditions, characterised by different particle size) and in field VIII (fine-grained homogeneous suspension of pelagic type) (after Passega, Byramjee 1969). The samples are in the Q-R segment (graded suspension), P-Q segment (graded suspension with some grain transported by rolling) and Tc zone (density runoff) (Fig. 7C) (after Passega 1964; Szmańda 2011). The SPAN curve shows clear peaks, which suggests a change in the transport force of grains at particular depths. 

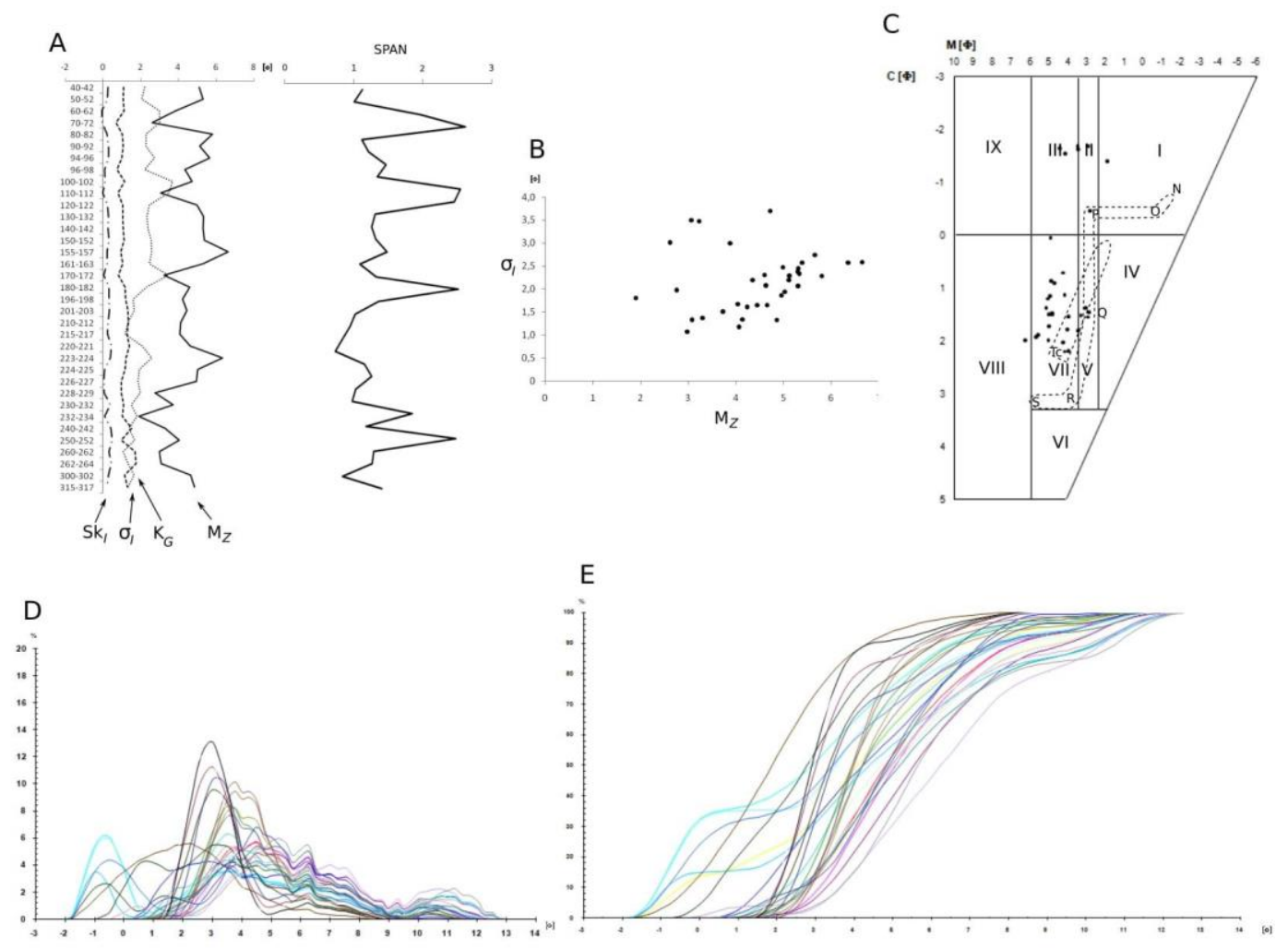

Fig. 7. Textural features of central zone sediments of gully $\mathrm{C}$

explanations in Fig. 3

In the distal zone, a significant drop in grain size and an increased share of coarse grains (skewness drop and negative values) are visible from a depth of 272 to $200 \mathrm{~cm}$ b.g.l., which suggests an increase in the transport force, though the sorting values do not fluctuate too much, which suggests that then there were not very dynamic conditions for the transport of grains with low variability of force. The graining frequency curve shows the greatest share of grains in sizes from 0 to $2 \mathrm{phi}$, then the share of finer grains systematically and evenly decreases. Thus, sudden accumulation episodes with high transport force (accumulation of coarser grains) prevailed, followed by a gradual, slow and relatively long decrease in transport force (accumulation of finer material). At the top of the profile, the values of the average grain diameter decrease, and the share of fine grains increases, so fine material is accumulated, which is associated with a decrease in the grain-transporting force. Two populations of points can be distinguished in the $\mathrm{M}_{\mathrm{Z}^{-}}$ versus- $\sigma_{\text {I }}$ relation. The first population is samples for a depth of 297 to $270 \mathrm{~cm}$ and from 122 to $30 \mathrm{~cm}$ b.g.l. ( $2^{\text {nd }}$ system $)$ and the second population is samples from 248 to $200 \mathrm{~cm}$ b.g.l. ( $1^{\text {st }}$ system $)$. For all samples, the $\mathrm{M}_{\mathrm{Z}}$-versus- $\sigma_{\mathrm{I}}$ relation exhibits the $3^{\text {rd }}$ system, and it is aeolian deposits of the moderate climate zone, overbank-pool deposits (MycielskaDowgiałło 1995; Mycielska-Dowgiałło, Ludwikowska-Kędzia 2001). Using the proposed code that can be described: $3^{\text {rd }}\left(2^{\text {nd }}, 1^{\text {st }}, 2^{\text {nd }}\right)$ system. On the Passega C/M diagram, two point populations can also be distinguished. The first population is identical to the first population identified for the $\mathrm{M}_{\mathrm{Z}^{-}}$ versus- $\sigma_{\mathrm{I}}$ relation. This population is located in fields I and II, where the deposition was from traction with a small proportion of suspension and in $\mathrm{N}-\mathrm{O}$ segment (rolling) and O-P segment (rolling with some grain transported in suspension). The second population is identical to the second population in the $\mathrm{M}_{\mathrm{Z}}$-versus- $\sigma_{\mathrm{I}}$ relation. This population is located in field VI/VII (gradation suspension transported in low turbulence conditions characterised by different particle-size distribution) and some samples are in the Tc zone (Fig. 8C) (after Passega 1964; Passega, Byramjee 1969; Szmańda 2011). The SPAN index values slowly increase from bottom to a depth of 240-242 cm b.g.l. reaching the value of 3.1 , then falling to the ceiling. 

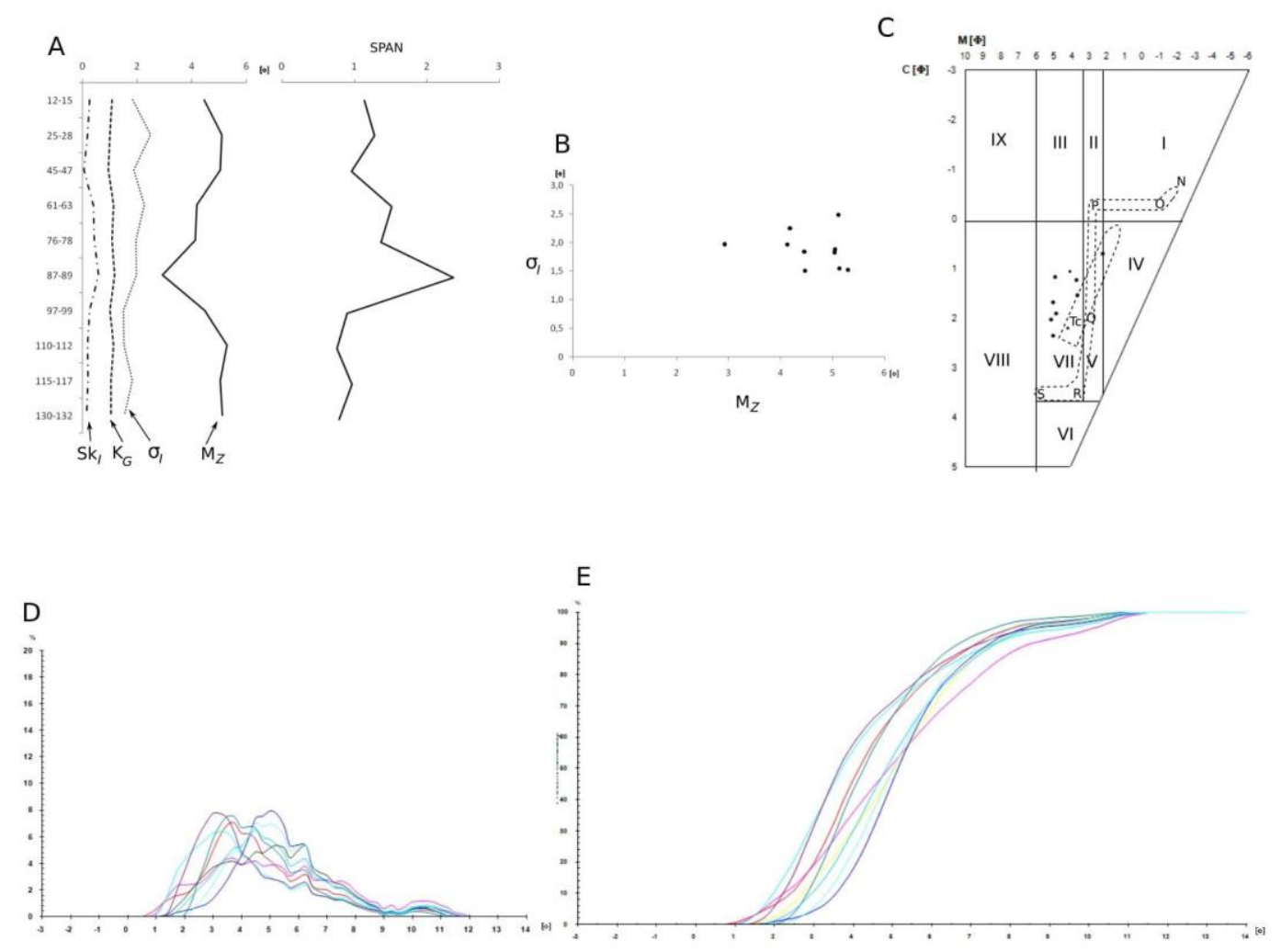

Fig. 8. Textural features of distal zone sediments of gully $\mathrm{C}$

explanations in Fig. 3

\section{$\underline{\text { STA (western part of the valley) }}$}

The STA profile is located within the smaller accumulative fan formed in the northern zone, between the slopes of the upland and the main accumulative fan of gully C. Profile STA is associated with the younger phase of development of gully $\mathrm{C}$.

The thickness of the fan sediments is less than $140 \mathrm{~cm}$. The bottom part of the fan is made of brown-grey laminated mud. Above, there are fine and medium sands with an admixture of silt. From a depth of $25 \mathrm{~cm}$ b.g.l., there are grey laminated mud sands. The top of the organic deposits underlying the fan sediment was dated to $4926 \pm 22 \mathrm{BP}$ (MKLA4683), i.e. to $3707-3662 \mathrm{cal}$. BC.

The sediments of this fan are fine sands and the skewness values are not very high. The lower segment of the profile (130-87 cm b.g.l.) is characterised by a slightly better sorting (but still poor) than the upper segment ( $87-15 \mathrm{~cm}$ b.g.l.). Poor sorting is caused by the short transport distance of the deposits, as well as the sudden deliveries of mixed material. In this case, the short transport route can be considered worse sorting, as the average grain diameter in this profile oscillates around 5 phi, which indicates the advantage of accumulative processes over erosive ones. However, from the different course of the particle-size distribution frequency curves, it can be concluded that the processes shaping the fan were quite dynamic - where there was a sudden accumulation of poorly sorted material. Perhaps from single events, i.e. heavy rains. The $\mathrm{M}_{\mathrm{z}}$-versus- $\sigma_{\mathrm{I}}$ relation shows the features of the $4^{\text {th }}$ system (slope sediments formed by splashing of rain drops). These sediments are visibly enriched with fractions of the order of $10-11$ phi. This is most likely due to the proximity of the slope, and to a fan of organic matter and clay material (whose transport started during the smallest surface runoff) being washed into the sediments. On the other hand, the clay material may have come from the long-term washing processes of clay horizons documented in the upland area. Poor sorting and the diversified course of the curves can also be explained by the transport of whole grain aggregates agglomerated with clay. The material was transported mainly in the saltation process and in suspension, with rolling being a minor part. In the percentage of samples in the Passega C/M diagram, $90 \%$ of the samples fall on the field VI/VII, and $10 \%$ on the field IV (after Passega, Byramjee 1969). The samples are in the Q- R segment (graded suspension) and $\mathrm{P}-\mathrm{Q}$ segment (graded suspension with some grain transported by rolling) and in the Tc zone (Fig. 9C) (after Passega 1964; Szmańda 2011). The highest values of the SPAN index are recorded at a depth of $87-89 \mathrm{~cm}$ b.g.l. (2.4). 

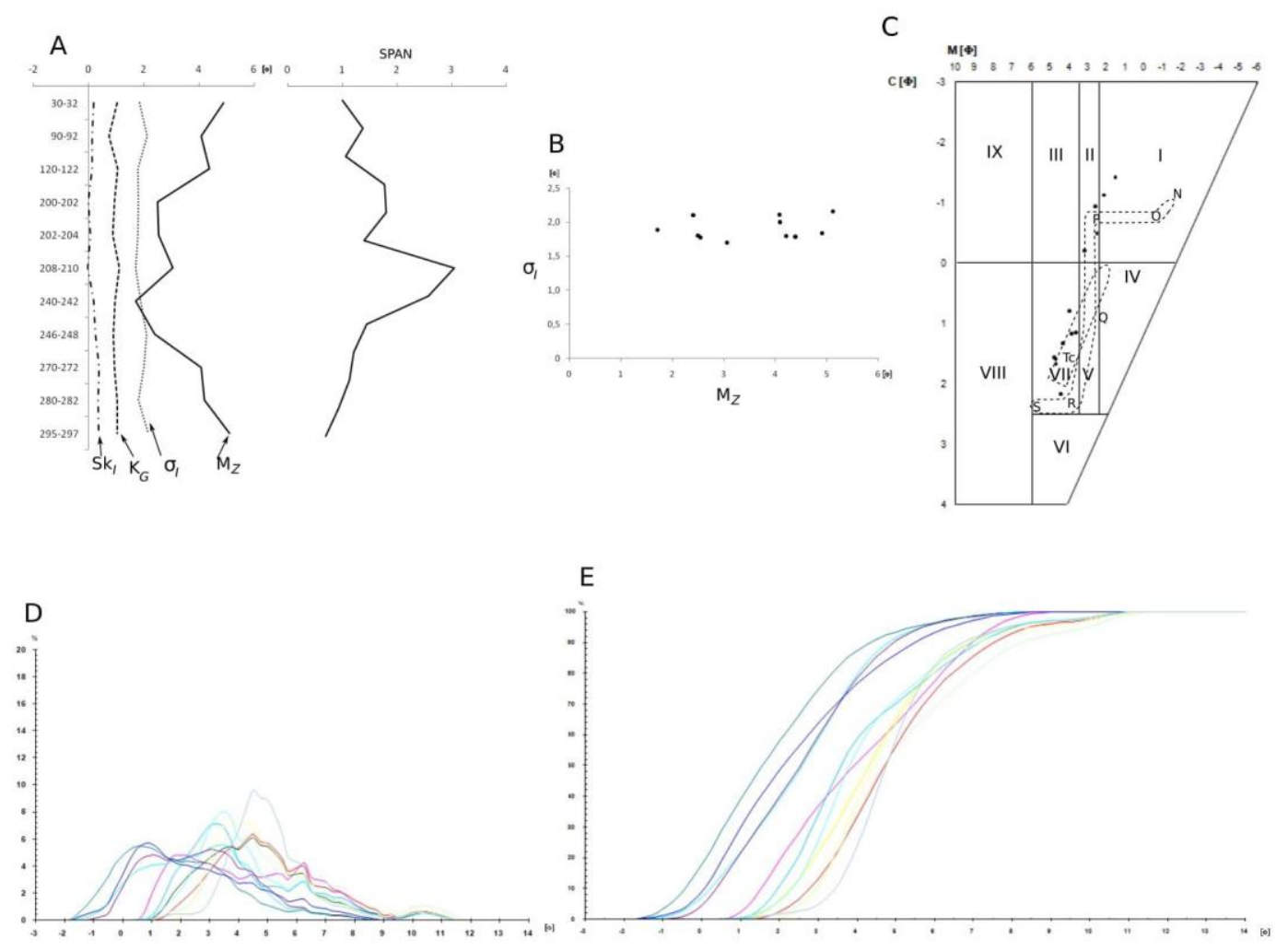

Fig. 9. Textural features of STA sediments of gully C

explanations in Fig. 3

\section{Denudational valley $\mathrm{D}$ \\ (eastern part of the valley)}

In the current morphology of the terrain, this gully is characterised by gentle slopes reaching only $10^{\circ}$. The bottom of the ravine is filled mainly with fine and medium sediments, and its length is now about $50 \mathrm{~m}$, although in the past its length could have been greater because it is now followed by a dirt road (Piech et al. 2020).

The fan deposits covered clay deposits, possibly kame material. Above, there are fine and medium, light-brown sands with some low laminations. Various sands occur at different depths. From 166 to $114 \mathrm{~cm}$ b.g.l., there are alternating fine, grey sands with silty admixtures and grey silts. Above, there are fine, light-brown, slightly silty sands. The fan is about $280 \mathrm{~cm}$ thick.

The bottom sample represents the sediments underlying the sediments of the accumulative fans. It is evident that they differ significantly from younger sediments. The average grain diameter decreases visibly with depth, so the erosive processes slowly were replaced by domination of accumulation processes. The material is poorly sorted here. The duality of the profile is noticeable in the skewness. In the lower part, finer grains are decidedly more common. They may have been deposited as a result of aeolian processes. The samples' $\mathrm{M}_{\mathrm{Z}}$-versus- $\sigma_{\mathrm{I}}$ relation indicates the presence of the $2^{\text {nd }}$ system (e.g. wash-out deposits), but there are also $3^{\text {rd }}$ system features (aeolian deposits of the moderate climate zone, overbank-pool deposits). It can be described as a $2^{\text {nd }} / 3^{\text {rd }}$ system. The particlesize distribution frequency curvesshow layers are enriched with the finest material (e.g. from aggregates). All curves are multimodal, which indicates short transport and variability of dynamics. There is a small share of traction in the transport of grains, and saltation dominates here. In the Passega $\mathrm{C} / \mathrm{M}$ diagram, more than $90 \%$ of the samples are in field VI/VII, and about $8 \%$ in field V (after Passega, Byramjee 1969). At the same time, they are in the $\mathrm{P}-\mathrm{Q}$ segment (graded suspension with some grain transported by rolling) and the Tc zone (Fig. 10C) (after Passega 1964; Szmańda 2011). Fluctuations in the value of the SPAN index are visible. These fluctuations decrease at the ceiling.

Denudational valley $\mathrm{E}$ (eastern part of the valley)

In morphology parameters, this gully is very similar to the D gully. However, the mouth part is multi-level - three levels can be distinguished, 

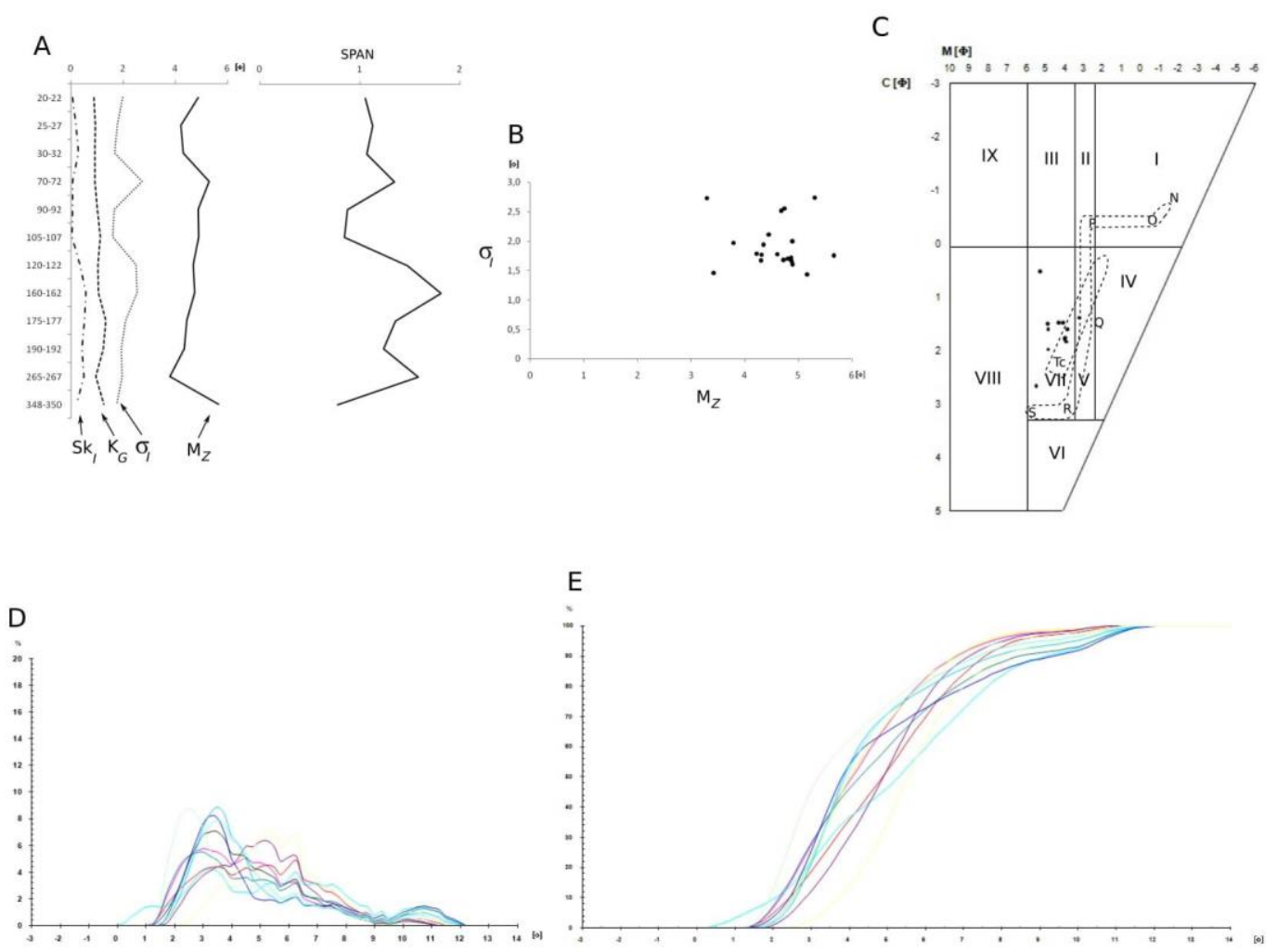

Fig. 10. Textural features of central zone sediments of gully D

explanations in Fig. 3

the outlet level is suspended in relation to the accumulative fan below. Perhaps we are dealing here with the transformation of isolated concave forms - non-outflow depressions of predominantly glacial origin. They are forming initially closed systems, and later, in the process of erosion, open flow systems were formed (Klatkowa 1989; Twardy 2017). The periglacial denudation valleys were the forms along which such transformations took place most effectively. There was both the filling of the insulated non-outflow forms and rapid erosion through mechanical denudation of the thresholds separating the individual concave forms (Klatkowa 1989; Twardy 2017). On the other hand, it cannot be ruled out that there will be later human interference that could develop such levels as a result of long-term land cultivation.

The sediments of the fan in the central part cover clay sediments. From a depth of 173 to 135 $\mathrm{cm}$ b.g.l. there are grey silts in places with single fragments of plant detritus. From a depth of 135 to $90 \mathrm{~cm}$ b.g.l. there is a silty material coloured from grey-greenish to dark brown. Above, there are fine, weakly laminated sands. The thickness of the fan in this part is approx. $250 \mathrm{~cm}$. The bottom of the fan in the distal zone is formed by silty fine sands with weak laminations. Above, there are silty fine sands, with light-brown colour.
The lower part of the fan in the central zone is characterised by lower $\mathrm{M}_{\mathrm{Z}}$ values and, at the same time, higher sorting values. This proves the higher transport force of the deposition and the sudden delivery of poorly sorted material. Then, the erosionaccumulation processes stabilised, as evidenced by relatively high values of the mean grain diameter, in the range of 4-5 phi. In the entire profile, the sediments are poorly sorted. Interestingly, skewness values are several times higher in the lower part of the fan than in the higher part. This may indicate that the finest fractions are being blown out or washed out. In the $\mathrm{M}_{\mathrm{Z}}$-versus- $\sigma_{\mathrm{I}}$ relation, the samples have the characteristics of the $1^{\text {st }}$ system (channel deposits). The particle-size distribution frequency curves are multimodal. Two samples have a very distinct mode and a relatively flat plateau for grain sizes from 3 to 7 phi. This speaks of the long sorting of the material and subsequent systematic washing on the previously deposited surface. The cumulative curves show a high proportion of rolling in the grain-transport type, which indicates a higher grain-transport force. In the Passega $\mathrm{C} / \mathrm{M}$ diagram, samples from this segment are in fields IV and V, indicating that the deposition was from gradation suspension transported under conditions of high and moderate turbulence (after Passega, Byramjee 1969). These samples are in the 
P-Q transport field segment, which is graded suspension with some grain transported by rolling. Saltation dominated in the remaining samples, and in the Passega $\mathrm{C} / \mathrm{M}$ diagram the samples were in field VI/VII and in the P-Q segment (graded suspension with some grain transported by rolling) and in the Tc zone (Fig. 11C) (after Passega 1964; Szmańda 2011). The highest values of the SPAN index are visible at the bottom of the profile. Above the value, they are constant and oscillate around 0.95 .
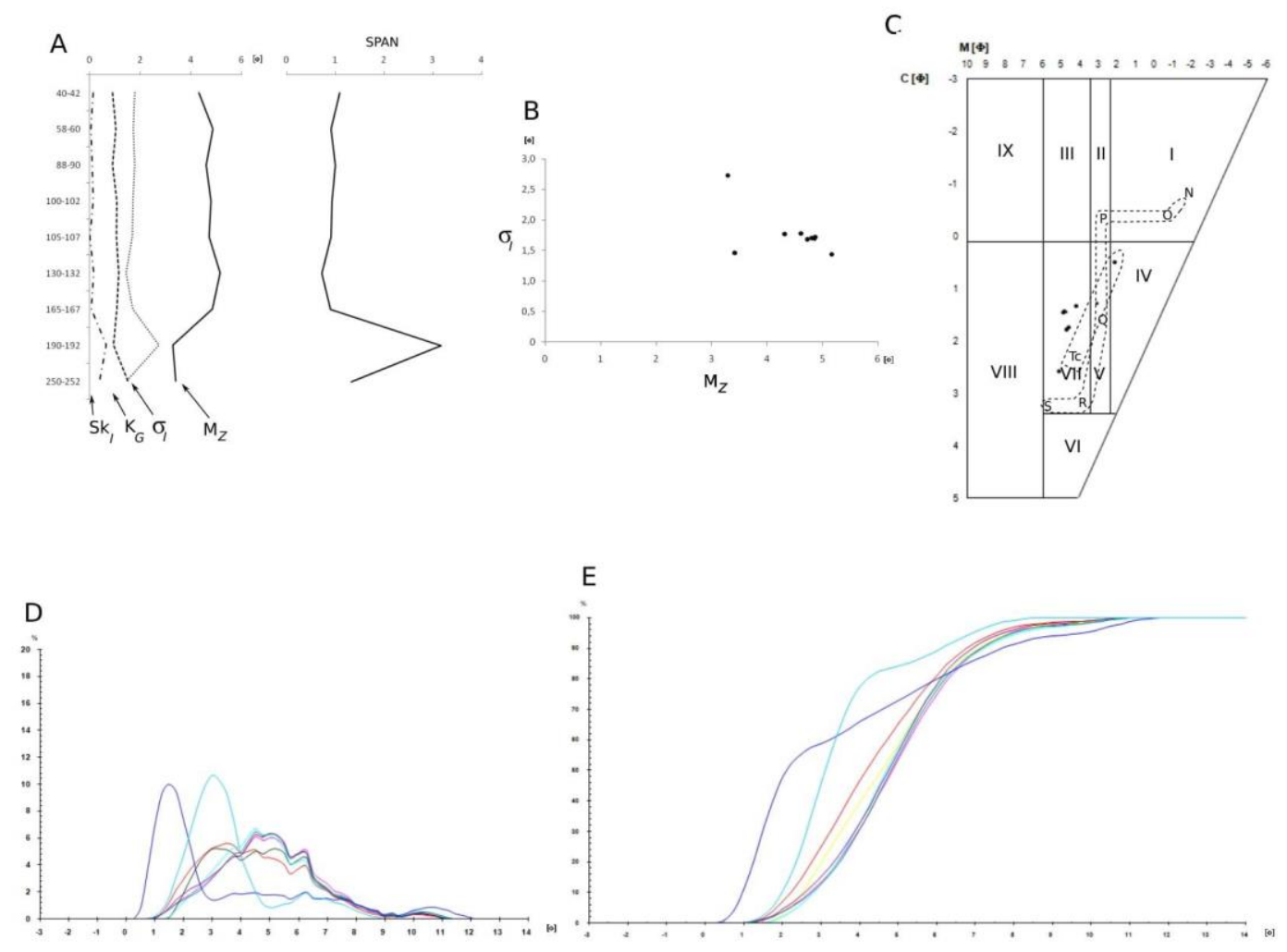

Fig. 11. Textural features of central zone sediments of gully $\mathrm{E}$

explanations in Fig. 3

In the distal zone, based on changes in the values of the mean grain diameter and skewness, it can be concluded that in the past there have been numerous changes in the intensity of the erosion and slope processes in favour of the predominance of erosion, and then accumulation. The characteristic feature of this profile is the constancy of the sorting values - slight variations around the value of 2. In the $\mathrm{M}_{\mathrm{Z}}$-versus- $\sigma_{I}$ relation, we recognise the $3^{\text {rd }}$ system, which refers to aeolian deposits of the moderate climate zone, or overbank-pool deposits. It is a characteristic system for low-dynamic sedimentological environments with low variation of transport force. Two groups of points can be distinguished here, i.e. one with values below 4 phi, the other with values above 4 phi. The former most likely relates to the erosive stages of washout and/or aeolian processes, where the finer grains are washed away/blown away, while the latter most likely relates to periods with increased accumulation. It is well visible in the particle-size distribution frequency curves. In the first group, there are curves with the largest particle size in the range of values 1-2 phi. The second group consists of curves, the share of grains in the size of 5-6 phi is dominant, and the sorting takes place in the coarser fraction or accumulation of aggregates. In the Passega $\mathrm{C} / \mathrm{M}$ diagram, the samples are in field VI/VII (44.4\%) and field V (56.6\%) and simultaneously in the $\mathrm{P}-\mathrm{Q}$ segment and in the Tc zone (Fig. 12). This demonstrates the domination of the low graintransport force in low-turbulence conditions (after Passega 1964; Passega, Byramjee 1969; Szmańda 2011). This profile shows large fluctuations in the SPAN index from 1 to 1.2 . 

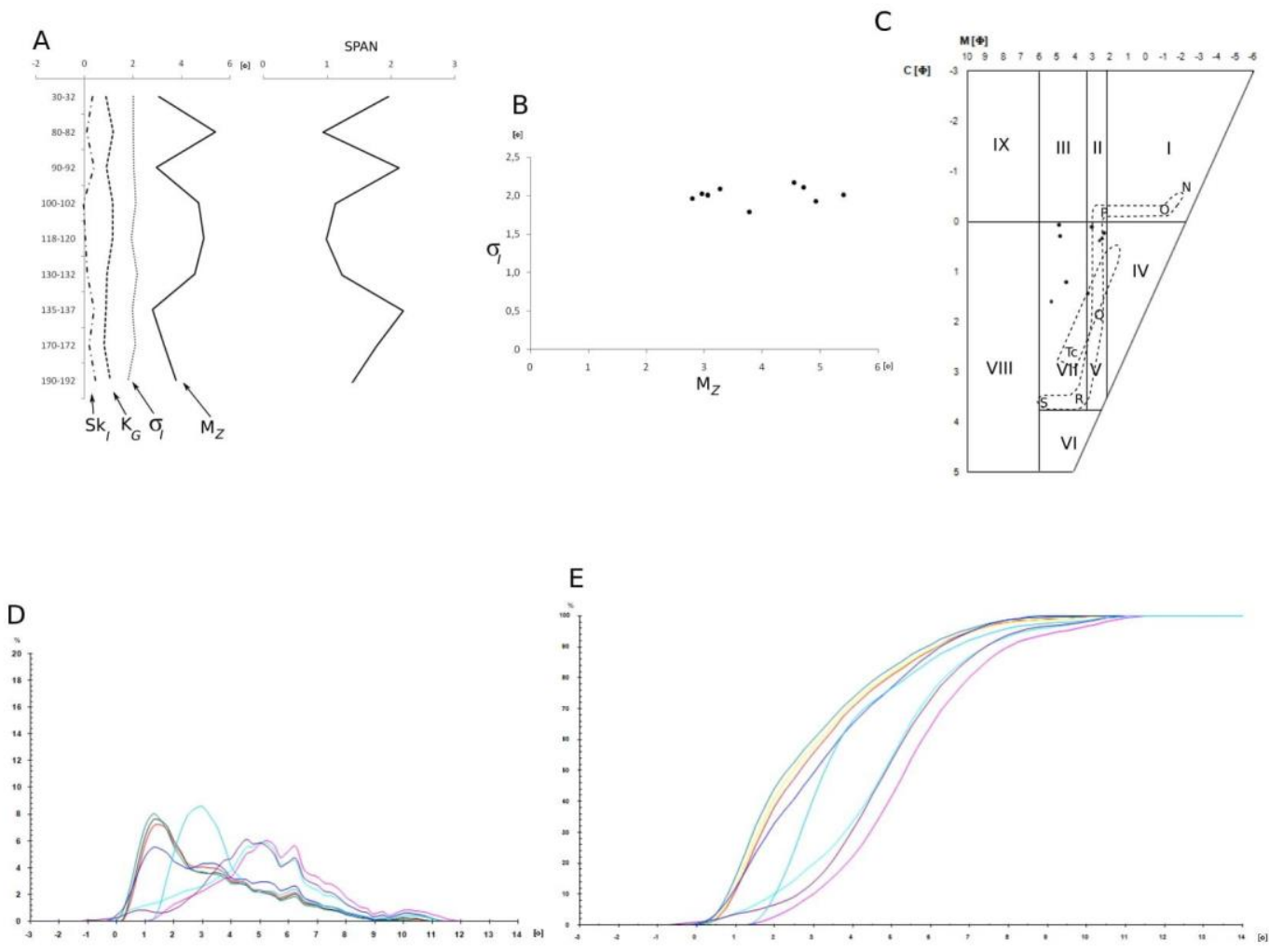

Fig. 12. Textural features of distal zone sediments of gully E explanations in Fig. 3

Denudational valley $\mathrm{F}$

\section{(eastern part of the valley)}

In terms of morphometry, this is similar to gullies $\mathrm{E}$ and $\mathrm{D}$. The gradients of the slopes amount to a maximum of $15^{\circ}$, the current depth is approx. $2 \mathrm{~m}$, and the bottom is approx. $10 \mathrm{~m}$ wide.

Here, the sediments of the fan cover fluvioglacial sediments. Above, there are deposits of grey silt to a depth of $104 \mathrm{~cm}$ b.g.l. Next, there are lightbrown fine sand, slightly silty. At a depth of 66 and $29 \mathrm{~cm}$ b.g.l. there are single charcoals. Here, the thickness of the sediments of the fan is less than $2 \mathrm{~m}$.

From the bottom to the depth of $65 \mathrm{~cm}$ b.g.l., slight fluctuations in average grain diameter are noted. This could indicate a stable accumulation environment or stable permanent sediment feed, but strong fluctuations in sorting are noted from the floor to a depth of $110 \mathrm{~cm}$. For all samples, the $1^{\text {st }}$ system can be specified in the $\mathrm{M}_{\mathrm{Z}}$-versus- $\sigma_{\mathrm{I}}$ relation, where an environment characterised by high variability of the force transporting the material. Periods of shortterm increased flow are separated by periods of low flow dynamics. In low-dynamic periods, sorting of the material by transport by saltation dominates. During periods of increased flow, there were rapid drops in the transport force, and as a result the accumulation of coarse material prevails (Mycielska-Dowgiałło
1995). From $222 \mathrm{~cm}$ to $122 \mathrm{~cm}$ b.g.l. the $1^{\text {st }}$ system is recognised. Then, from a depth of 112 to $65 \mathrm{~cm}$ b.g.l., relatively constant $\mathrm{M}_{Z}$ values and a slowly deteriorating sorting are visible. This indicates a change to the $4^{\text {th }}$ system, i.e. slope sediments formed by splashing of rain drops. The top part of the profile $(62-28 \mathrm{~cm}$ b.g.l.) is transformed into the $3^{\text {rd }}$ system, where the dynamics of the sedimentological environment are low, with low variation in the transport force. For the entire profile, in relation $M_{z}$-versus- $\sigma_{\mathrm{I}}$, the samples assume the $1^{\text {st }}$ system. For this profile, the code can be used: $1^{\text {st }}\left(1^{\text {st }}, 4^{\text {th }}, 3^{\text {rd }}\right)$ system. The vast majority of the particle-size distribution frequency curves are multimodal. This may indicate multiple transformations of previously accumulated sediments or poor transformation of source sediments. In the Passega C/M diagram, more than $94 \%$ of the samples are in the VI/VI and they are very close to Q-R segment (graded suspension) and Tc zone. In turn, one sample $(60-62 \mathrm{~cm}$ b.g.l.) is located in I segment, where traction deposition dominates with a small share of suspension. At the same time, this sample is in the O-P segment (rolling with some grain transported in suspension) (Fig. 13C) (after Passega 1964; Passega, Byramjee 1969). Throughout the profile, the SPAN values remain relatively constant at around 1 . The only exception is the depth of $60-62 \mathrm{~cm}$ b.g.l., where the value is 2.5 . 

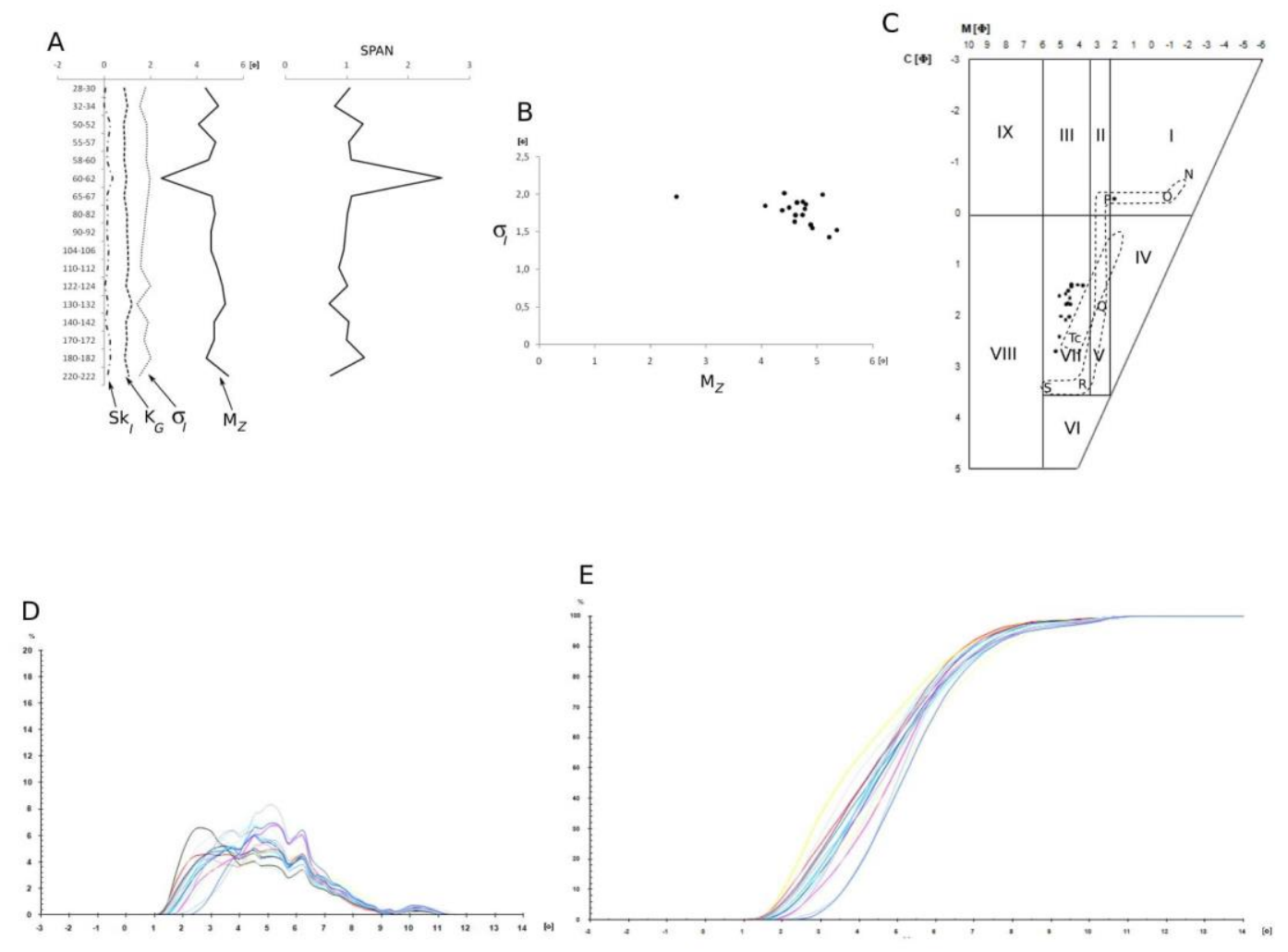

Fig. 13. Textural features of central zone sediments of gully $\mathrm{F}$

explanations in Fig. 3

Denudational valley $\mathrm{G}$

(eastern part of the valley)

In the morphology and morphometry of the gullies, this one does not stand out from gullies D, $\mathrm{E}$ and $\mathrm{F}$. The bottom of the fan up to $130 \mathrm{~cm} \mathrm{b.g.l.}$ (in the central part) is made of fine silty sands with fine clay balls. Above, there are fine sands, weakly laminated. The top is made of fine and medium brown sands.

The sediments of this fan have high mean grain diameters (4-6 phi) and poor or very poor sorting. Based on sedimentological indicators, two units can be distinguished: the first from the bottom to a depth of $132 \mathrm{~cm} \mathrm{b.g.l.,} \mathrm{the} \mathrm{second} \mathrm{from}$ $130 \mathrm{~cm}$ b.g.l. to the top. The first fragment demonstrates fluctuations in the mean grain diameter, sorting and skewness. In the $\mathrm{M}_{\mathrm{Z}}$-versus- $\sigma_{\mathrm{I}}$ relation, the $2^{\text {nd }}$ system is distinguished. In the second fragment, the charts are expropriated. From the depth of $92 \mathrm{~cm}$ b.g.l., a steady, slow decrease in the mean grain diameter is visible. On the other hand, an "arc" is visible in the skewness diagram. Here the samples also assume the $2^{\text {nd }}$ system. In this system, sorting takes place mainly in coarser fractions and periodic supply of poorly sorted material. It is characteristic of, among other things, slope wash deposits. In the other hand, for the entire profile, in the $\mathrm{M}_{\mathrm{Z}}$-versus- $\sigma_{\mathrm{I}}$ relation, the features of the $1^{\text {st }}$ system can be found. For a detailed distinction, it would be necessary to use the following notation: $1^{\text {st }}\left(2^{\text {nd }}, 2^{\text {nd }}\right)$ system. The particle-size distribution frequency curves are usually unimodal, and less often bimodal and trimodal. All curves are basically expropriated - no mod hits $8 \%$. For single samples, a large share of rolling in the transport of grains is marked, and saltation prevails. However, there is also a significant share of transport in suspension. This is most likely the result of the washing of clay balls. In the Passega C/M diagram, 85\% of the samples are in field VI/VII and $15 \%$ are in field III (dominant deposition from traction with a small proportion of suspension). A few samples are in the Tc zone, but most of the samples are outside the transport field segments (they are close to the Q-R segment) (Fig. 14C) (after Passega 1964; Passega, Byramjee 1969). From the bottom to a depth of $122 \mathrm{~cm}$ b.g.l., large fluctuations in the SPAN value are visible, above this depth the values are characterised by uniformity. 

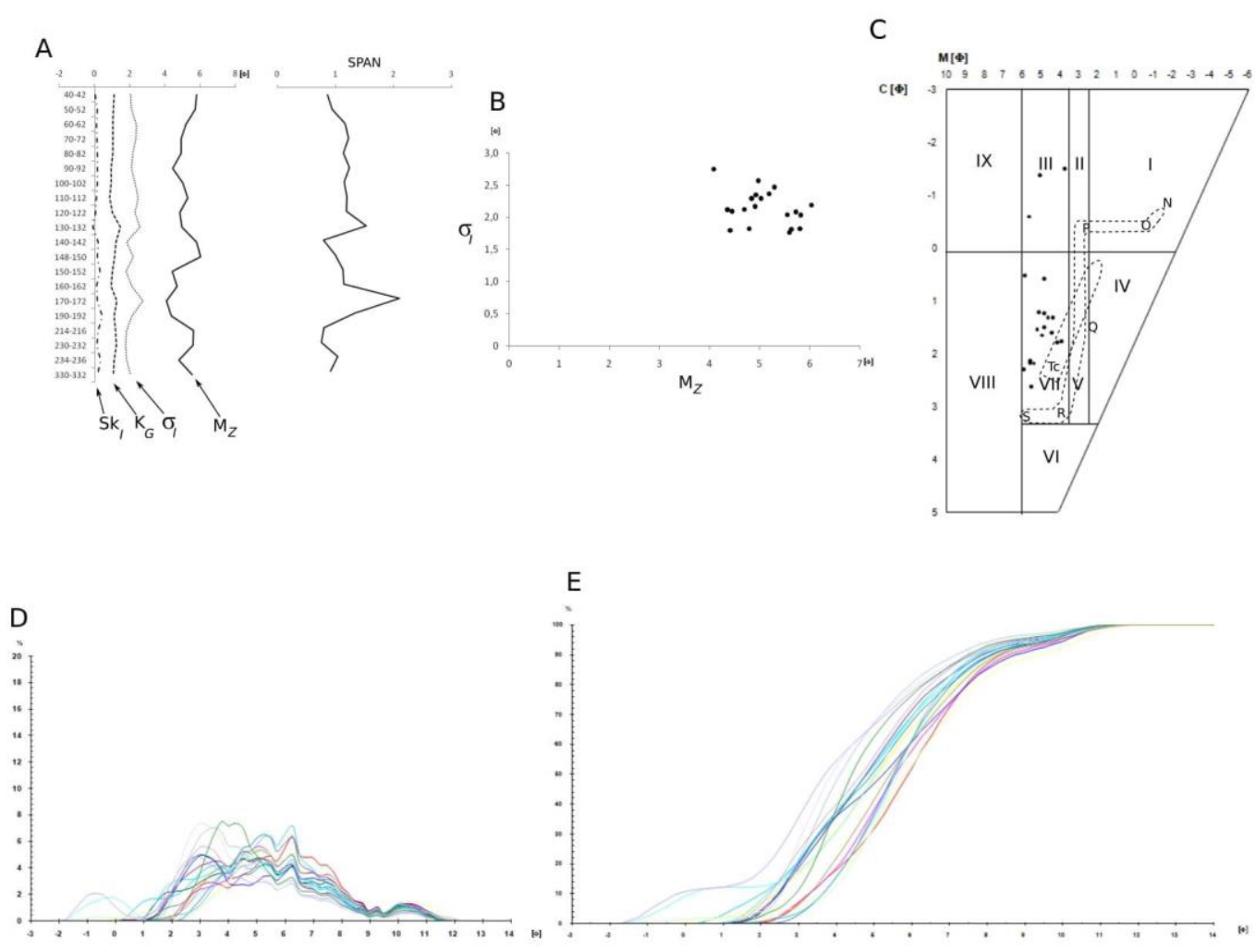

Fig. 14. Textural features of central zone sediments of gully $\mathrm{F}$ explanations in Fig. 3

\section{Discussion}

\section{Sedimentological characteristics of the Sertaya gullies and denudational valleys}

Deluvial sediments can often retain the characteristics of the source material (Smolska 2005; Twardy 2008; Kittel 2014; Majewski 2017; Piech et al. 2018).

In the diagram of the $\mathrm{M}_{\mathrm{Z}}$-versus- $\sigma_{\mathrm{I}}$ relation, the vast majority of the obtained points are arranged according to the $2^{\text {nd }}$ system after MycielskaDowgiałło (1995) and Mycielska-Dowgiałło, Ludwikowska-Kędzia (2011) (Fig. 15). However, the situation is much more complex, as shown in Table 2. The studied deluvia are characterised by the dominance of grains with a size of 3-4 phi, but the sizes may be different, depending on the source material. The recorded sorting also varies from poorly sorted to well sorted material, except that poorly sorted sediments predominate. This is mainly due to the short transport distance of grains and the weak grain-transporting force. Positive skewness values predominate. The $2^{\text {nd }}$ system in the $\mathrm{M}_{\mathrm{Z}}$-versus- $\sigma_{\mathrm{I}}$ relation is typical for deluvial sediments (Smolska 2005; Twardy 2008; Mycielska-Dowgiałło, Ludwikowska-Kędzia 2011;
Paluszkiewicz 2011; Kittel 2014; RatajczakSzczerba, Paluszkiewicz 2015; Majewski 2017; Piech et al. 2018).

Western fans have unimodal curves and in the

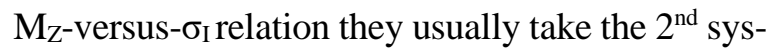
tem (e.g. wash-out deposits). The $\mathrm{M}_{\mathrm{Z}}$-versus- $\sigma_{\mathrm{I}}$ relation shows that the sediments of the fans belonging to gullies A and B are clearly closer to the beginning of the system than the remaining sediments (Fig. 15). This separation may be influenced by the source material. For gullies A and B, the source material is mainly fine fluvioglacial sands, while for the remaining gully, apart from the fluvioglacial sands, there are also glacial tills.

The sediments of the western accumulative fans (A, B) can be classified as deluvial sands after Twardy (2008), where the grain size is predominant in the range of 1-3 phi, poor or medium sorting is noted, and the skewness values are varied. The $2^{\text {nd }}$ system is marked for these sediments after Mycielska-Dowgiałło (1995). The particle-size distribution curves take an unimodal form. The main processes shaping the series of deluvial sands are linear rain-wash, which in upland areas creates furrows that cross the accumulation level of soils. The material was transported mainly by traction and saltation, and the subsequent units are relatively flat and continuous layers (Twardy 2008). 
Eastern fans have multimodal curves and assume the $1^{\text {st }}, 2^{\text {nd }}, 3^{\text {rd }}$ and $4^{\text {th }}$ systems. Moreover, these sediments exhibit more complex $\mathrm{M}_{\mathrm{Z} \text {-versus- }}$ $\sigma_{\mathrm{I}}$ relations. Eastern fans were also formed as a result of surface runoffs, but also rinsing from rain, or solifluction and creeping. Perhaps the aeolian factor also influenced the system of the $\mathrm{M}_{\mathrm{Z}}$-versus$\sigma_{I}$ relation here. In the investigated fans' sediments (C distal zone, D, E distal zone), segments were found in which the graining characteristics in the $\mathrm{M}_{\mathrm{Z}}$-versus- $\sigma_{\mathrm{I}}$ diagram suggest the presence of the $2^{\text {nd }}$ and $3^{\text {th }}$ system, which correspond to aeolian deposits of hot desert and aeolian deposits of the moderate climate zone (after Mycielska-Dowgiałło, Ludwikowska-Kędzia 2011). However, the sediments of the studied fans are not in the area intended for aeolian sediments in the diagram (Fig. 4 in Podgórski, Szmańda 2004).

The sediments of fans on the eastern side of the Serteyka valley (gullies and denudational valleys D, E, F, G) can be classified as deluvial sandy silt in the concept of Twardy (2008). They are characterised by fine fraction (values higher than 3 phi), poor and very poor sorting. They are also characterised by weak affiliation to the $1^{\text {st }}$ or $2^{\text {nd }}$ system and usually positive values of skewness. The particle-size distribution frequency curves are polymodal, and the cumulative curves run in a way in which it is impossible to clearly distinguish individual sections determining the form of transport. Twardy (2008) believes that such sediments were formed in a low dynamic sedimentological environment, where diffuse flushing prevailed, which works mainly within the topsoil. Twardy (2008) indicates that poor and very poor sorting is the result of unstable runoff conditions on the slopes. Smolska (2005) suggests that the poor separation of the population on the cumulative curves may be typical for deluvial sediments, which is confirmed by the results of Majewski (2017), although the work of Paluszkiewicz (2011) and Kittel (2014) managed to distinguish differences.

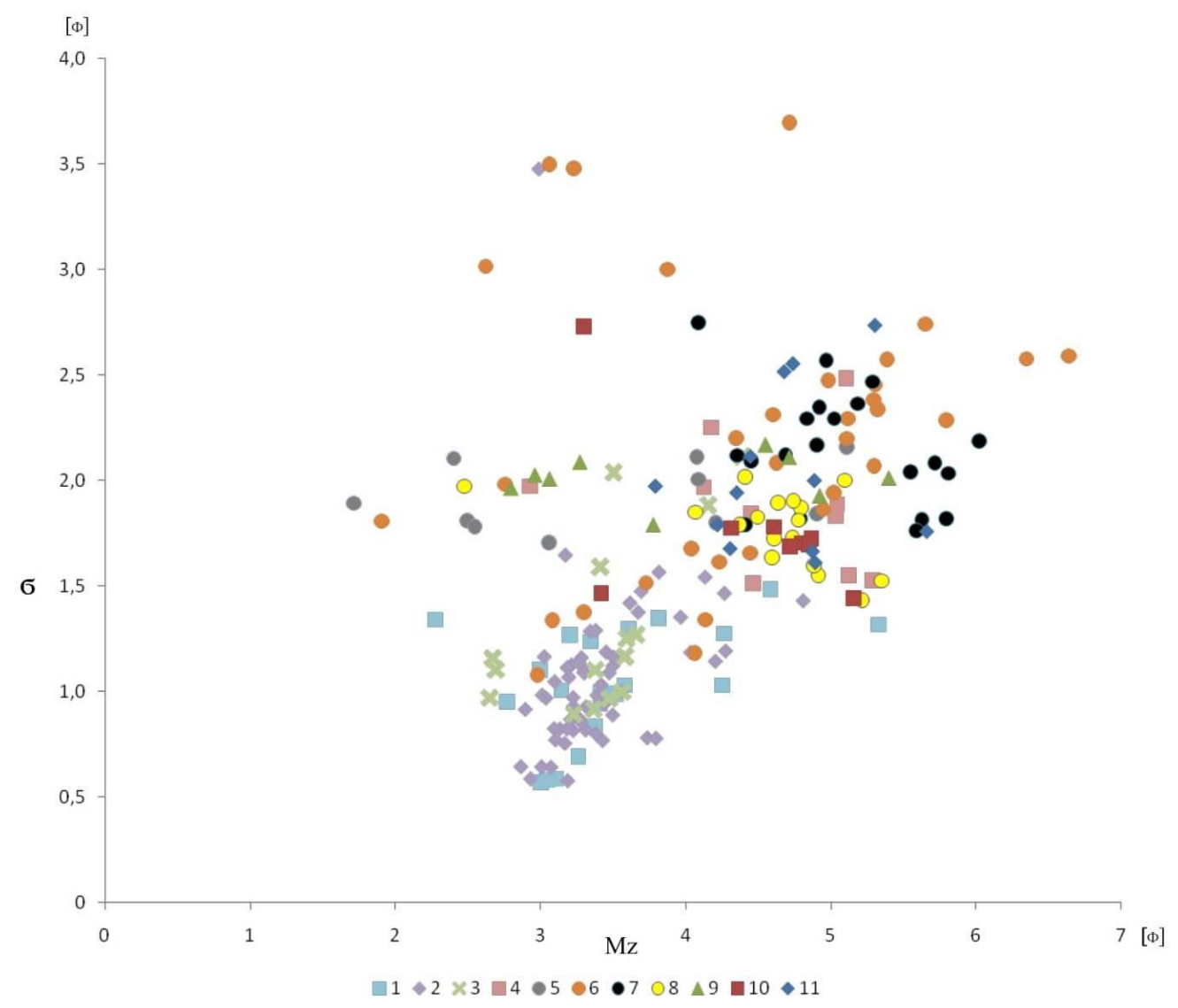

Fig. 15. Graph of relationship between mean diameter and sorting for all tested sediments

1 - gully A central zone; 2 - gully A distal zone; 3 - gully B central zone; 4 - gully C central zone; 5 - gully C distal zone; 6 - C gully C STA profile; 7 - gully D central zone; 8 - gully E central zone; 9 - gully E distal zone; 10 - gully F central zone; 11 - gully G central zone 


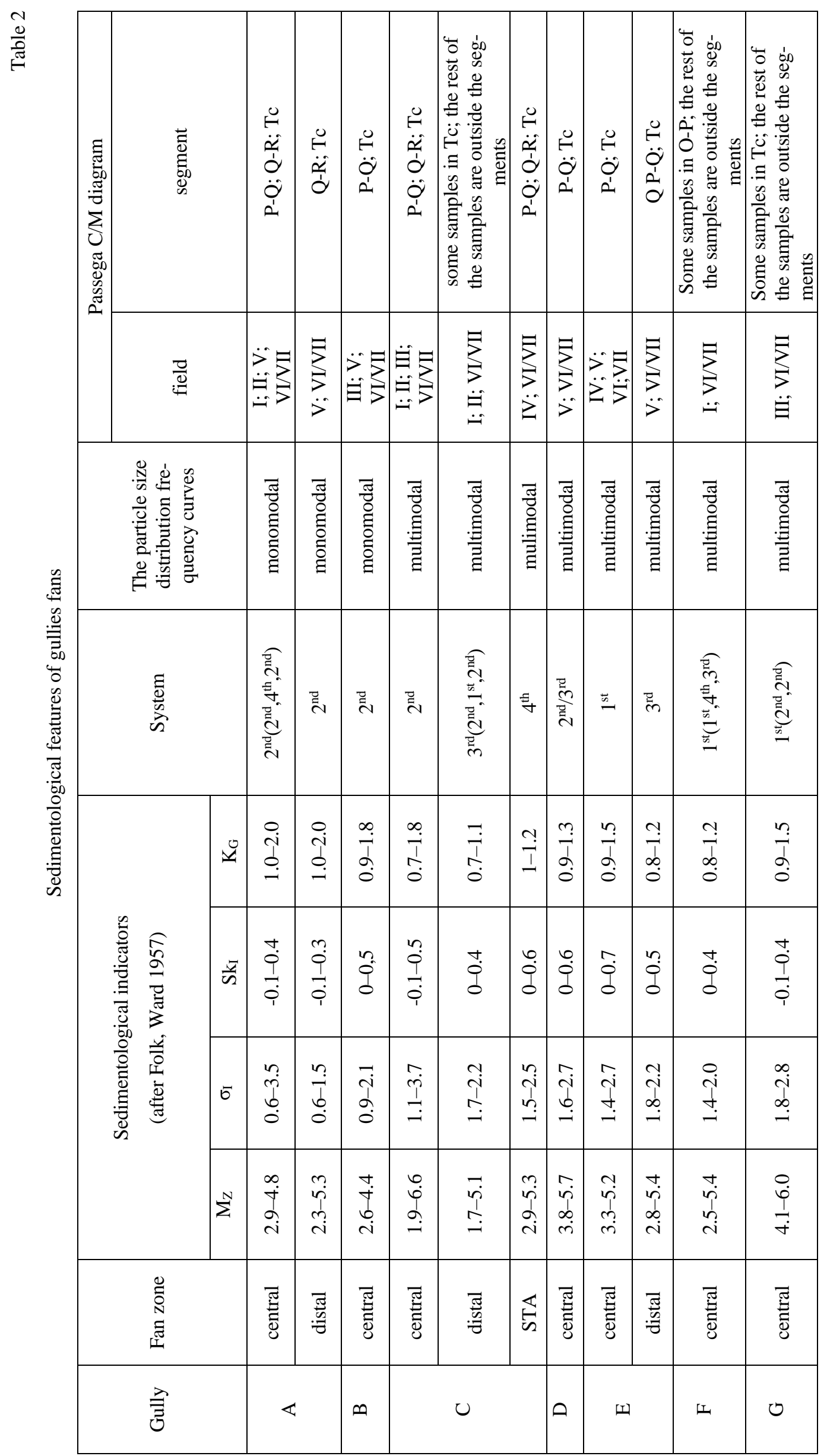


The geological structure of the deluvia separation does not affect the presented model (Twardy 2008). In the work of Twardy (2008), the source material for slope sediments includes sands and silts of kames, glacial sands and gravels, ablation/till clays, and silty sands. At the same time, cuts were formed on the slopes of kames, river terraces, fluvioglacial plains and the slopes of moraine plateaus. The model is not affected by the terrain relief area or large water arteries, nor by longlasting settlement traditions (after Twardy 2008).

The sediments of the western fans have lower mean grains values than those of the eastern fans. The deposits of the first group of fans are better sorted and have larger ranges of values for skewness and kurtosis.

Coarse sediments appeared in individual places in the sediments of Serteya accumulative fans, which can be interpreted as proluvia. Proluvia are multi-grained sediments, with a predominance of coarse grains, with poor or very poor sorting with low or negative skewness values. Their particle-size distribution frequency curves can take various shapes. The $1^{\text {st }}$ system (channel deposits) is characteristic for these sediments, which is confirmed by the results of Smolska (2005) and Twardy (2008).

In all relationships of sedimentological indicators, there is a clear division between gullies from the modern period and from the periglacial/early Holocene period (Fig. 15). The modern slope deposits are coarser and better sorted than the older slope deposits. The observed system in the diagram of the relationship $\mathrm{M}_{\mathrm{Z}^{-}}$versus- $\sigma_{\mathrm{I}}$ and $\mathrm{M}_{\mathrm{Z}^{-}}$ versus- $\mathrm{Sk}_{\mathrm{I}}$ is consistent with the concept of dividing deluvia into deluvial sands and deluvial sandy silt proposed by Twardy (2008). Where earlymodern sediments in Serteyka River valley correspond to deluvial sands, and older deluvial sediments correspond to sandy silt. The $\mathrm{M}_{\mathrm{Z}}$-versus-Sk diagram in modern sediments (deluvial sands) shows the tendency that the mean grain diameter (in phi values) increases with skewness values (Fig. 16). On the other hand, in the periglacial/early Holocene sediments (deluvial sandy dust) there is a tendency that the skewness values decrease with an increase in the mean grain diameter (in phi values).

In the $\mathrm{M}_{\mathrm{Z}}$-versus- $\mathrm{K}_{\mathrm{G}}$ relation, early modern sediments fall mainly in one grain-size range (3-4 phi), but there is a significant differentiation in the values of kurtosis, where leptokurtic distributions dominate. The sediments usually oscillate around one kurtosis value, but there is a large grain-size range. In the $\sigma_{\mathrm{I}}$-versus-Sk $\mathrm{Sk}_{\mathrm{I}}$ relation, a very clear positive trend is visible in early modern sediments, with predominant samples with better sorting than in older sediments. For the latter, the population of points is placed parallel to the skewness axis. In the $\sigma_{\mathrm{I}}$-versus- $\mathrm{K}_{\mathrm{G}}$ relation, new sediments form a point cloud with a relatively high degree of dispersion, while older sediments accumulate around the value of 1 phi for kurtosis and 1.5 to 2.5 phi for sorting. In the $\mathrm{K}_{\mathrm{G}}$-versus-Sk $\mathrm{K}_{\mathrm{I}}$ relation, the points for both series "start" in the same field, i.e. 1 phi values for kurtosis and 0 for skewness. Further, the population of samples for modern sediments follows a positive trend, while samples of older sediments accumulate around the value of 1 phi for kurtosis, with strongly different values of skewness.

The description of the $\mathrm{M}_{\mathrm{Z}^{-} \text {-versus- }} \sigma_{\mathrm{I}}$ and $\mathrm{M}_{\mathrm{Z}^{-}}$ versus-Sk $\mathrm{K}_{\mathrm{I}}$ relationships for deluvial sandy silt (after Twardy 2008) can also be extended to include trends for other relationships of sedimentological indicators. Characteristic features of this type of sediment also correspond to the features of sediments from the periglacial/early Holocene period. Perhaps the described features (as well as the concept) can be implemented in the recognition of slope deposits from this period, and perhaps they can be considered as typical features.

In the Passega C/M diagram, the sediments of the western fans are in fields I-VII, but the dominant fields are $\mathrm{V}$ (gradation suspension transported under moderate turbulence) and VI/VII (gradation suspension transported in conditions of low turbulence characterised by a different particle-size distribution). Segment $\mathrm{P}-\mathrm{Q}$ (graded suspension with some grain transported by rolling) dominates in transport, and Q-R segment (graded suspension) is also common. In all profiles, the samples were arranged in the Tc zone, which corresponds to the dense runoff. Western deluvia are formed as a result of dispersed and/or concentrated surface runoffs, with different dynamics. The very short time of gully A and B development indicates that there was less chance of multiple redeposition of sediments within the fan, and that human activity, including plowing within the upland, had a direct impact on the formation of these fans (Piech et al. 2018, 2020; Ginter et al. under review).

The sediments of eastern fans in the Passega $\mathrm{C} / \mathrm{M}$ diagram are located mainly in field VI/VII, so the deposition took place from the gradation suspension transported under low-turbulence conditions and from a homogeneous suspension with different graining. At the same time, the $\mathrm{P}-\mathrm{Q}$ segment and the Tc zone dominate here. Older deposits of D, E, F and G fans were accumulated and then could be transformed many times during 

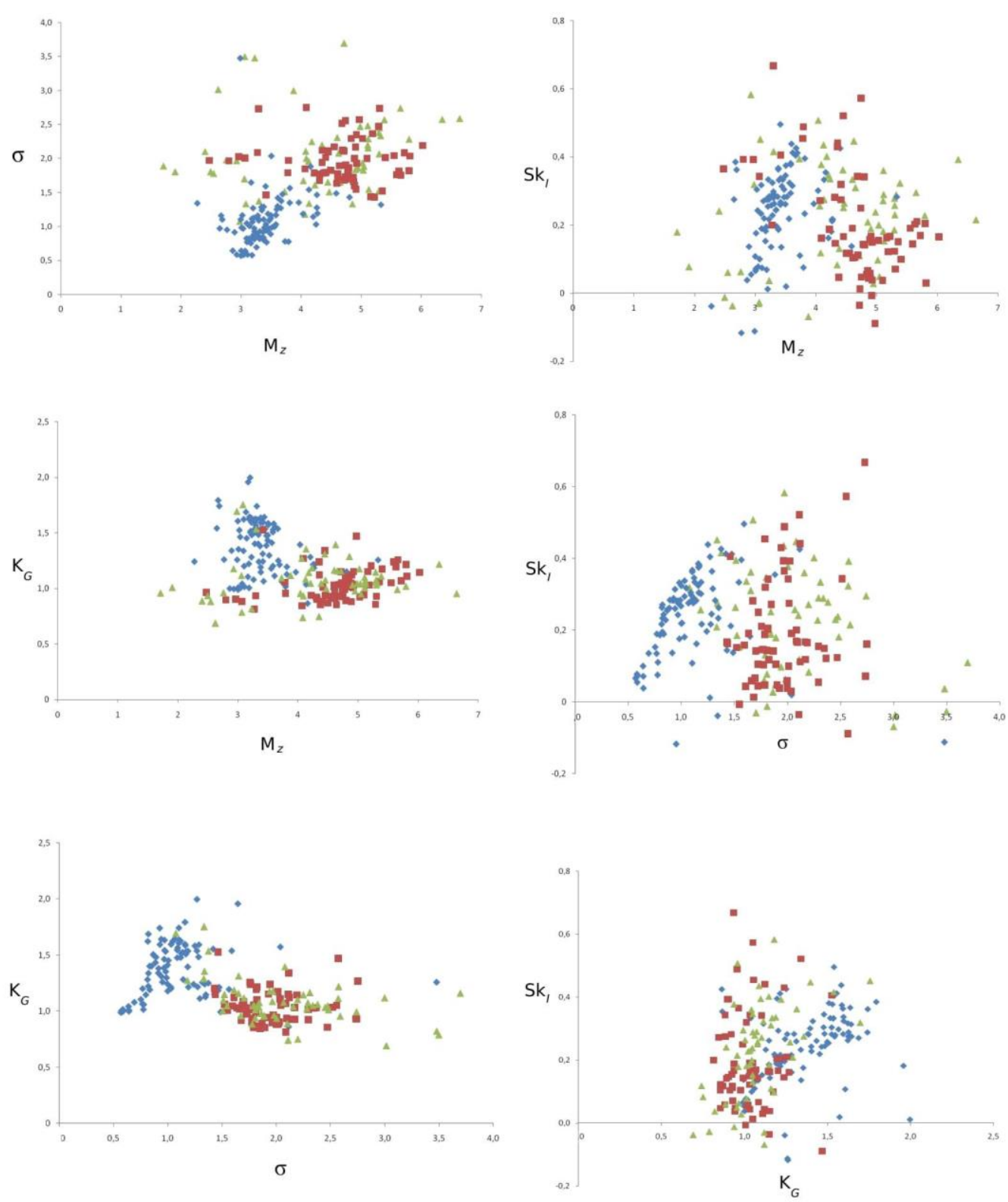

- $1=-2 \wedge-3$

Fig. 16. Relationships of sedimentological indicators for sediments of western and eastern fans (in phi scale) 1 - deposits of A and B fan; 2 - deposits of D, E, F, G fan; 3 - deposits of C fan

different and changing environmental conditions. The accumulation of these sediments could have continued (perhaps intermittently) after the retreat of the Weichselian (Valdai) ice sheet.

In the Passega C/M diagram, proluvia's points accumulate in the areas of deposit environment types I, II and III. The deposition is from traction with a small share of suspension dominates and at the same time are in the transport segments (or close to them) $\mathrm{N}-\mathrm{O}$ (rolling) and in $\mathrm{O}-\mathrm{P}$ (rolling with some grain transported in suspension). This is consistent with the analyses of Smolska (2005), although in her results, the progeny accumulated in the $\mathrm{P}-\mathrm{Q}$ and $\mathrm{O}-\mathrm{P}$ segments. Proluvia arise as a result of concentrated surface runoff, sometimes of extreme intensity (Smolska 2005; Twardy 2008; Piech et al. 2018). The particle-size distribution frequency curves for proluvia are unimodal with an elongated left slope as demonstrated by Twardy (2008). By contrast, for the gully A fan, the proluvia are polymodal, with an elongated left and right slope of the curve (Piech et al. 2018). The cumulative curves show a clear advantage of traction in the grain-transport process (Twardy 2008; Piech $e t$ al. 2018). 
For fans $\mathrm{A}$ and $\mathrm{B}$, the average value of the SPAN index is 0.8 with a range of 0.3 to 2.7. For fans $\mathrm{D}, \mathrm{E}, \mathrm{F}$ and $\mathrm{G}$, the mean of the index is 1.2 (0.7-3.2), while for fan $C$, the mean is the highest and amounts to 1.4 with a range from 0.7 to 3.1. This suggests that fans A and B show the greatest environment dynamics, while for the remaining fans the variability of the sedimentological environment is slightly lower (cf. Warrier et al. 2016).The arithmetic mean of the SPAN index for all samples is 1.1 , with a range of 0.3-3.2. These results differ from the range of values for late Quaternary lacustrine sediments, where the range is from about 2 to even 7.8 (Warrier et al. 2016). In turn, from the studies by Foster et al. (2008), the SPAN range for lacustrine sediments ranges from about 2 to almost 20 with the mean of the index is 6.83. Perhaps the SPAN index can be another parameter to distinguish deluvial sediments.

The sediments of fans A and B are concentrated in the fields with graining characteristics similar to those of moraine tills, sandbed braided river deposits and Vistula River overbank deposits comparing with Podgórski and Szmańda's research (2004). In turn, the features of the sediments of the C, D, E, F, and G fans are similar to the features of the sediments of moraine tills, Vistula River overbank deposits and varved clays from Podgórski and Szmańda's research (2004).

In almost all samples, the particle-size distribution curves show that the curves for particle size finer than 6 phi are arranged almost identically to each other (with different particle size shares). The lower fraction content in the samples is the result of the fraction size limits marked during lithological studies (Szmańda 2011 - further literature there). The greater or lesser content of the individual fraction ranges is also caused by Tanner gaps. These are the ranges determined by Tanner (1958), where when changing the value of $\mathrm{M}_{Z}$ decreases the grain diameter of the basic fractions (Szmańda 2011). For the investigated sediments of accumulative fans, the decrease in the frequency of grain occurrence is noticeable mainly in the range of 9$10 \mathrm{phi}$, but also, to a lesser extent, in the range of 5-6 phi.

To determine all the characteristic deluvia parameters, detailed statistical analysis should be performed, the analysis of which goes beyond the accepted scope of this paper. Statistical analysis that would be worthwhile include analysis of variance and F. Snedecor's test, which check the validity of grouping sediments. This method was used by Turkowska (1991), who in her research showed that the statistical analysis of the particle-size distribution can determine the features of the river sedimentation environment. The graining indexes differentiate channel and overbank alluvia at the significance level of $1 \%$, where $\mathrm{M}_{\mathrm{Z}}$ has the greatest differentiating power (Turkowska 1991).

The erosive area of western gullies is most probably much larger than that of eastern gullies. The result is a longer transport route for the grains and a greater chance of better sorting of the material. In the vicinity of gullies A and B, there are layers of clay of small thickness and they are located several dozen metres away from the studied gullies. Thus, the proportion of clay balls in the fan's sediments may be lower. In addition, clay balls were found only in proluvial layers, not in the deluvial deposits. Most likely, during heavy downpours, the erosion surface at the upland was much larger and perhaps it cut the layers of clay further away from the gullies. Human impact, i.e. land deforestation, agricultural use of the upland may have an impact on the breaking up aggregates and a greater share of the smallest fractions. The result may be the unimodality of the deluvia of fans A and B.

Gullies and denudational valleys D, E, F and G may have been formed during the Late Weichselian, which is suggested by their poorly delineated morphology and filling of the bottom with deluvial sediments. Fan deposits directly cover fluvio- and limnoglacial deposits, so it was not possible to date them using the ${ }^{14} \mathrm{C}$ method. This also suggests the older age of these forms. In the lower part of these denudational valleys, finer grains are definitely more common. They may have been deposited as a result of aeolian processes, which is partially confirmed by the results of the in the diagram of the relationship $\mathrm{M}_{\mathrm{Z}}$-versus- $\sigma_{\mathrm{I}}$ analysis. This is most likely the result of exposed ground and sparse vegetation. This is confirmed by the research of Taravov et al. (2019), where patchy vegetation with tundra-steppe and forest associations for this period was documented in biogenic sediments from the Serteyka region.

The deposits of fan $\mathrm{C}$ have been accumulated since the early Holocene, as evidenced by the presence of these deposits directly on kame sediments. This is also evidenced by the points in the relationships of sedimentological indicators, the greater part of which accumulates with the points corresponding to the eastern fans. Some of the samples, however, are in the population corresponding to modern settlements. It can be assumed that gully $\mathrm{C}$ and its fan were rejuvenated in the modern period.

The clay on the eastern slopes is in the immediate vicinity of the denudational valleys, and its thickness is greater. The multimodality of the sedi- 
ments of the eastern fans is associated with the washing of clay surfaces, and further with the transport of whole grain aggregates combined with clay and their subsequent erosion. In the process of shaping gullies, which is assumed to be periglacial, solifluction and runoff processes take place, and perhaps also the processes of stripping and falling off the frozen fragments of the gully's slopes and their subsequent washing out (see Klatkowa 1965, 1989; Twardy 2008; Paluszkiewicz 2011; Tylman 2011; Belyaev et al. 2020). As a result of these processes, the sediments are mixed, with almost no sorting, which results in poor and very poor sorting. The so-formed covers were then cut open and blurred by the processes of linear erosion and surface runoff. Another important element was the runoff of water on the frozen ground, and then the erosion of the adjacent layer (Klatkowa 1965; Majewski 2008; Tylman 2011; Karasiewicz et al. 2019). In turn, Panin et al. (2011) believe that slope wash was the main process shaping the slopes during the decline of the last ice age. Massive sands and sandy silts interpreted as colluvia (with a massive structure) could have arisen as a result of creeping (Majewski, Paluszkiewicz 2019). In turn, massive sands and silty sands (with an average grain diameter from -0.5 to 6.3 phi and with a poor and moderate sorting) could also arise as a result of flushing occurring in the Late Weichselian and the early Holocene (Karasiewicz et al. 2019). Boulder levels are associated with gravitational movements within the slopes in the cold periods of these periods (Tylman 2011; Majewski 2014; Majewski, Paluszkiewicz 2019). To the Late Weichselian, in the denudation valleys of the Łódz Upland (Central Poland), series of fine-laminated sands are documented, and under them there are Plenivistulian boulder horizons (Klatkowa 1965, 1989). In the denudation valleys from the Plenivistulian, sandy-silty series were also found (Twardy 2008). Their mean grain diameter varies from 1 to $4.5 \mathrm{phi}$, with poor and very poor sorting. The skewness values are positive but stay close to 0 . Vistulian slope sediments are unimodal, with the dominant mode falling to values close to 2 phi (Twardy 2008). Smolska (2005) notes that some of the slope sediments were deposited in the periglacial and early Holocene periods. This material is laminated and is deposited on glacial and fluvioglacial sediments, and has a thickness of about $0.5 \mathrm{~m}$. In the top, soliflucent structures and a lack of organic matter were noticeable. The slope sediments from this period are better sorted than the Holocene deluvia. This is due to a large content of aeolian material (Smolska 2005).
In Stochlak's (1996) distinction, sandy, sandysilty sediments, often characterised by lamination, belong to the "proper" Holocene deluvia. They are characterised by a large amount of humus admixture and rhythmic layers. This author also distinguishes agricultural deluvia, which are identical to tillage diamicton (Sinkiewicz 1998; Smolska 2005; Twardy 2008). On the other hand, Teisseyre (1994) distinguishes deluvial soil sands as detrital sediments composed of soil lumps, where they constitute more than $75 \%$ of the sediment volume.

The western and eastern gullies also differ in terms of morphology and morphometry. Western forms were cut further and deeper into the area of the upland. The slope can reach even $70^{\circ}$, and the slopes within the ravines are short. Their upper edges are sometimes jagged due to modern erosion processes. The bottom of the gullies in its upper part has a V-shaped character, while at the mouth it has a U-shaped form. The bottom is additionally incised due to early modern erosion. The fans formed at the mouths of these forms may be up to $70 \mathrm{~m}$ long and up to $60 \mathrm{~m}$ wide, and are visible in the relief. It should be mentioned that the western slopes of the Serteyka River valley are steeper than the eastern slopes.

The gullies and denudational valley on the eastern side of the valley are much shorter than the western forms. Their slopes are long and have gradients of up to $20^{\circ}$. The whole forms are poorly defined in the morphology of the terrain relief and has a U-shaped character. The bottom is wide and flat, and filled with deluvial sediments. Modern erosion phases have not been documented here. The fans in this zone are very poorly visible - they are partially buried by lake sediments (mainly gyttja), as well as overbank alluvia.

\section{The chronology of gullies}

The slope processes within the Serteyka River valley most likely began shortly after the last ice sheet receded in the Late Weichselian. At that time, the water from the melting blocks of dead ice was discharged to channels and to/from depressions conditioned by uneven fluvioglacial procesess (Klatkowa 1965, 1989; Sinkiewicz 1989; Smolska 2005; Majewski 2008). Periglacial conditions prevailed at that time, i.e. no compacts of vegetation and frozen ground. Solifluction, rain-wash and thaw processes acted on the slopes. In turn, the factors influencing the development of nivation hollows are solifluction, frost ventilation and flushing (Thorn, Hall 2001; Paluszkiewicz 2014; Ratajczak-Szczerba, Paluszkiewicz 2015). The next 
stage in the development of valleys and gullies was the Bølling, when the temperature increased slightly, which resulted in permafrost thawing and the erosion phase (Kozarski 1995; Marks 1996; Tobolski 1998; Hoek 2001; Majewski 2008). In the period of 20-15 ka BP, the oldest gorges/gullies and small river valleys could have been formed in Eastern Europe (Belyaev et al. 2005, 2020; Panin et al. 2009). In the Early Holocene (10.3-8.4 ka BP), the development of valleys was stopped by the development of plant cover (Starkel 1990 - further literature there; Twardy et al. 2014; Twardy 2017).

Panin et al. (2011) describe the stages of gully erosion that took place in the Russian Plain during the Holocene. These phases were in the periods: 6200-5900, 5500-5200, 4600-4300 and 36003000 cal. years BP. In the Serteya region in the period of 5.9-4.2 cal. BP, the local climate could have been shaped by a lake-river system (Mroczkowska et al. 2021a). During this period, numerous fluctuations in the water level in the Great Serteya Palaeolake Basin were recorded (Tarasov et al. 2019; Kittel et al. 2020, 2021; Mroczkowska et al. 2021a; Wieckowska-Lüth et al. 2021).

Short episodes or single episodes of increased erosion occurred at the Russian Plain also as follows: 4700, 3800, 3000, 2200, 1800 and 900 years BP (Belyaev et al. 2005, 2020; Panin et al. 2009), which may partially correlate with the wet phases defined by Starkel (1990 - further literature; Starkel et al. 2013). They were correlated within creased activity, e.g. rivers or landslides. In turn, on the slopes of the Serteyka River valley, a significant intensification of the slope processes took place in the period 3250-2500 cal. BC and 22001500 BC (Kittel et al. 2020, 2021). Due to increased rainfalls, from 3000 cal. years BP, some of the studied gullies in Eastern Europe were created (Belyaev et al. 2005; Panin et al. 2009). The period 1800-1500 cal. years BP corresponds to the next phase of cutting up the surface of the plateaus. The increase in the development of erosive cuts was caused by the overlapping of climatic and anthropogenic factors (Belyaev et al. 2005; Twardy 2008, 2017; Panin et al. 2009, 2011; Zgłobicki et al. 2014; Kittel et al. 2018, 2020, 2021). The bottoms of periglacial valleys were built up in the Holocene by deluvia as a result of rain-wash, and then cut open due to human-induced gully erosion (Twardy 2017). It was during this period that gully $\mathrm{C}$ was most likely formed, the lateral STA accumulative fan of which is dated after ca. $3700 \mathrm{BC}$. However, it is very close to the slope, making the dated sediment vulnerable to the redeposition of older material.
Organic mud dated to $220 \pm 100$ and $430 \pm 100$ years conv. BP in the Central Plain of Russia, which has been documented within the gully, has been accumulated as a result of increased linear erosion and stripping of the humus layer from higher areas (Belyaev et al. 2005). During this period, an increase in the share of pollen from cultivated vegetation was noted in organic sediments found within gullies and accumulative fans (Belyaev et al. 2005; Panin et al. 2009, 2011). From the $11^{\text {th }}$ century AD, in the Central European Lowlands, the importance of erosion in shaping slopes increased. This was the result of human influence, and between the $14^{\text {th }}$ and $16^{\text {th }}$ centuries $\mathrm{AD}$, another increase in human impact on gully erosion was noted (Belyaev et al. 2005; Panin et al. 2009, 2011). Intensive exploitation of the environment took place in the $15^{\text {th }}$ century $\mathrm{AD}$, which resulted in new road cuts being made, among other things. Since the $17^{\text {th }}$ century AD, in the Central European Lowlands and in the Serteya region, intense deforestation and soil erosion resulting from agricultural activities have been recorded (Golosov et al. 2017; Piech et al. 2018; Tarasov et al. 2019; Łuców et al. 2020; Mroczkowska et al. 2021b; Ginter et al. under review). These processes were the cause of the development of gully erosion, and further the formation of slope covers (Golosov 2002; Golosov et al. 2017). Fans A and B were formed from the second half of the $17^{\text {th }}$ century to at least the $19^{\text {th }}$ century $\mathrm{AD}$ (see Ginter et al. under review). On the other hand, climate changes during the Little Ice Age also caused increased gully erosion (Twardy 2008; Panin et al. 2009; Zglobicki et al. 2014; Piech et al. 2018, 2020; Ginter et al. under review). During this period, the conditions were decidedly humid in the Serteya region (Mroczkowska et al. 2021b). In the 1990s, the erosion processes decreased due to the shrinkage of agricultural land. This was caused by, among other things, the collapse of collective farms (Golosov et al. 2017).

\section{Conclusions}

- Seven gullies and their accumulative fans of various sizes and ages have been documented in the lower part of the Serteyka River Valley within the Great Serteya Palaeolake Basin.

- The gullies on the western slope of the valley have a very distinct terrain morphology and are dated to the modern period (gullies A and B). Gully $\mathrm{C}$ may date to the periglacial period and been "rejuvenated" from about 3200 BC. 
- Gullies and denudational valleys on the eastern side of the valley (D, E, F, G) are poorly legible in the relief. Their slopes are gentle, their bottoms are filled with deluvial material and they were most likely formed in the periglacial conditions of the Late Weichselian.

- The complex geological structure of individual fans was documented, consisting mainly of fine sands with silty laminations, and also silts (deluvial deposits), and sometimes various sands with clay balls (proluvia) were recorded.

- These sedimentological features of the accumulative fan deposits indicate significant differentiation of dynamics in the erosion-accumulation environment.

- There are significant differences in the sedimentological characteristics between the western and eastern gullies, which indicates differences in the deposition conditions, the characteristics of the source material, and perhaps the time period over which the sediments were deposited.

- The sediments of modern fans were defined as deluvial sands, while the sediments of older fans are deluvial sandy silts (after Twardy 2008). In turn, the sediments of fan $C$ have the features of both deluvial sand and deluvial sand silt.

- The features of deluvial sandy silts (after Twardy 2008) can be extended to include analysis of other sedimentological indicators.

- The use of the aforementioned analysis and sedimentological methods allowed for a detailed characterization of slope sediments. It also allowed for an interpretative extension of the relationship between individual sedimentological indicators.

- Sedimentological analysis allowed for the determination of lithodynamic conditions that shaped the deposition of slope sediments.

- The proposed extended record of the systems of relations between sedimentological indicators allowed for a more detailed description of the tested samples from individual profiles.

\section{Acknowledgments}

I would like to thank two anonymous reviewers for constructive comments and suggestions that greatly improved manuscript. I would also like to thank Professor Piotr Kittel for all his help and advice. I would like to thank Andrey Mazurkewicz and the entire expedition from The State Hermitage Muzeum (St Petersburg, Russia) for the opportunity to conduct field research for this article. I would also like to thank Maciej Sadło, Aleksandra Cetwińska, Krzysztof Cetwiński, Katarzyna
Pilaszek and PhD Dariusz Manasterski for helping with the field work.

The research was a part of a project financed by a grant from the National Science Centre of Poland No. 2017/25/B/HS3/00274.

\section{References}

Belyaev V.R., Eremenko E.A., Panin A.V., Belyaev Y.R. 2005. Stages of late Holocene gully development in the central Russian plain. International Journal of Sediment Research 20(3): 224232.

Belyaev V.R., Garankina E.V., Shorkunov I.G., Konstantinov E.A., Rusakov A.V., Shishkina Y.V., Andreev P.V., Verlova T.A. 2020. Holocene erosion and deposition within a small catchment of the northeastern Borisoglebsk Upland (Central European Russia). IOP Conf. Series: Earth and Environmental Science 438: 1-17; DOI: 10.1088/1755-1315/438/1/012002.

Blott S., Pye K. 2001. Gradistat: a grain size distribution and statistics package for the analysis of unconsolidated sediments. Earth Surface Processes and Landform 26: 1237-1248.

Dotterweich M. 2008. The history of soil erosion and fluvial deposits in small catchments of Central Europe: Deciphering the long-term interaction between humans and the environment. Geomorphology 101: 192-208.

Dotterweich M., Rodzik J., Zgłobicki W., Schmitt A., Schmidtchen G., Bork H.R. 2012. High resolution gully erosion and sedimentation processes, and land use changes since the Bronze Age and future trajectories in the Kazimierz Dolny area (Nałęczów Plateau, SE-Poland). Catena 95: 5062.

Dreibrodt S., Lomax J., Nelle O., Lubos C., Fischer P., Mitusov A., Reiss S., Radtke U., Nadeau M., Grootes P.M., Bork H.R. 2010. Are mid-latitude slopes sensitive to climatic oscillations? Implications from an Early Holocene sequence of slope deposits and buried soils from eastern Germany. Geomorphology 122: 351-369.

Folk R.L., Ward W. 1957. Brazos River bar: A study in the significance of grain size parameters. Journal of Sedimentary Petrology 27: 3-26.

Foster I.D.I. 1991. High energy coastal sedimentary deposits; an evaluation of depositional processes in Southwest England. Earth Surface Processes and Landforms 16: 341-356.

Foster I.D.I., Oldfield F., Flower R.J., Keatings K. 2008. Mineral magnetic signatures in a long core from Lake Qarun, Middle Egypt. Journal of Paleolimnology 40: 835-849.

Ginter A., Piech W., Krąpiec M., Moska P., Sikorski J., Hrynowiecka A., Stachowicz-Rybka R., Mroczkowska A., Mazurkevich A., Kittel P. 2020. The age of deposition of accumulative fan sediments 
in Serteyka River Valley (Western Russia). Limnology and Freshwater Biology 4: 483-485; DOI:10.31951/2658-3518-2020-A-4-483.

Ginter A., Piech W., Krąpiec M., Moska P., Sikorski J., Hrynowiecka A., Stachowicz-Rybka R., Cywa K., Piotrowska N., Mroczkowska A., Tołoczko W., Okupny D., Mazurkevich A., Kittel P. (under revision). Intense and quick land relief transformation in the Little Ice Age: the age of accumulative fan deposits in Serteyka River Valley (Western Russia). Quaternary International.

Glosov V. 2002. Soil erosion and small river aggradation in Russia. Proceedings of 12th ISCO Conference, May 26-31, 2002. Tsinghua University Press, Beijing: 154-159.

Golosov V., Ivanova N., Kurbanova S. 2017. Influence of agricultural development and climate changes on the drainage valley density of the southern half of the Russian Plain. International Journal of Sediment Research 32(1): 60-72.

Gorlach A., Kalm V., Hang T. 2015. Thickness distribution of quaternary deposits in the formerly glaciated part of the East European plain. Journal of Maps 11(4): 6250635.

Hoek W.Z. 2001. Vegetation response to the $\sim 14,7$ and $\sim 11,5 \mathrm{ka}$ cal. BP climate transitions: is vegetation lagging climate? Global and Planetary Change 30: 103-115.

Jaworski J. 2018. Późnoglacjalny i holoceński rozwój dolinek erozyjno-denudacyjnych na wybranych przykładach zboczy dolin i rynien w krajobrazie młodoglacjalnym Polski Północnej. Wyd. Nauk. UMK, Toruń.

Karasiewicz T., Tobojko L., Świtoniak M., Milewska K., Tyszkowski S. 2019. The morphogenesis of erosional Valley in the slopes of the Drwęca valley and the properties of their colluvial infills. Bulletin of Geography. Physical Geography Series 16: 5-20.

Kittel P. 2014. Slope deposits as an indicato of anthropopressure in the light of research in Central Poland. Quaternary International 324: 34-55.

Kittel P. 2016. Badania geoarcheologiczne pokrywy stokowej na stanowisku archeologicznym Szynklew 11, gm. Pabianice. Acta Universitatis Lodziensis. Folia Geographica Physica 15: 25-35.

Kittel P., Mazurkevich A., Dolbunova E.V., Kazakov E., Mroczkowska A., Pavlovskaia E., Piech W., Płóciennik M., Sikora J., Teltevskaya Y., Wieckowska-Lüth M. 2018. Palaeoenvironmental reconstructions for the Neolithic pile-dwelling Serteya II site case study, Western Russia. Acta Geografica Lodzensia 107: 191-213.

Kittel P., Mazurkevich A., Alexandrovskiy A., Dolbunova E., Krupski M., Szmańda J., StachowiczRybka R., Cywa K., Mroczkowska A., Okupny D. 2020. Lacustrine, fluvial and slope deposits in the wetland shore area in Serteya, Western Russia. Acta Geographica Lodziensia 110: 103-124.
Kittel P., Mazurkevich A., Wieckowska-Lüth M., Pawłowski D., Dolbunova E., Płóciennik M., Gauthier E., Krąpiec M., Maigrot Y., Danger M., Mroczkowska A., Okupny D., Szmańda J., Thiebaut E., Słowiński M. 2021. On the border between land and water: The environmental conditions of the Neolithic occupation from 4.3 until $1.6 \mathrm{ka} \mathrm{BC}$ at Serteya, Western Russia. Geoarchaeology. An International Journal 36(2): 173202.

Klatkowa H. 1965. Niecki i doliny denudacyjne w okolicach Łodzi. Acta Geographica Lodziensia 19.

Klatkowa H. 1989. The incorporation of closed depressions into the open erosional system as one of the models of head valley fashioning in the Vistulian. Quaestiones Geographicae 2: 83-91.

Kozarski S. 1995. Deglacjacja północno-zachodniej Polski: warunki środowiska i transformacja geosystemu ( 20 ka -10 ka BP). Dokumentacja Geograficzna, 1, IGiPZ PAN.

Krumbein W.C. 1934. Size frequency distribution of sediments. Journal of Sedimentary Petrology 4: 65-77.

Kul'kova M.A., Mazurkevich A.N., Dolukhanov P.M. 2001. Chronology and palaeoclimate of prehistoric sites in Western Dvina-Lovat area of Northwestern Russia. Geochronometria 20: 87-94.

Kul'kova M.A., Mazurkevich A., Gerasimov D. 2015. Stone Age archaeological sites and environmental changes during the Holocene in the NW region of Russia. In: J. Harff, G. Bailey \& F. Lüth (eds.) Geology and Archaeology: Submerged Landscapes of the Continental Shelf. Geological Society: 27-50.

Łuców D., Lamentowicz M., Obremska M., Arkihipova M., Kittel P., Łokas E., Mazurkevicz A., Mróz T., Tjallingii R., Słowiński M. 2020. Disturbance and resilience of a Sphagnum peatland in western Russia (Western Dvina Lakeland) during the last 300 years: a multiproxy, high-resolution study. The Holocene 30(11): 1552-1566.

Majewski M. 2008. Ewolucja form i osadów stokowych $\mathrm{w}$ późnym vistulianie i holocenie w rynnie jeziora Jasień. Landform Analysis 7: 95-101.

Majewski M. 2014. Human impact on Subatlantic slopewash processes and land form development AT Lake Jasień (northern Poland). Quaternary International 324: 56-66.

Majewski M. 2017. Cechy uziarnienia deluwiów na tle osadów źródłowych na przykładzie zagłębień bezodpływowych w rejonie Łupawska (Pojezierze Zachodniopomorskie). Acta Geographica Lodziensia 106: 221-223.

Majewski M., Paluszkiewicz R. 2019. The origin and evolution of small dry valley in the last-glacial area on the example of the Pomeranian Lake District (Poland). Estonian Journal of Earth Sciences 68(1): 26-36. 
Marks L. 1996. Role of buried dead ice in modeling of lake bains in present lakelands. Acta Geographica Lodziensia 71: 181-193.

Mazurkevich A.N., Korotkevich B.N., Dolukhanov P.M., Shukurov A.M, Arslanov Kh.A., Savel'eva L.A., Dzinoridze E.N., Kulkova M.A., Zaitseva G.I. 2009a. Climate, subsistence and human movements in the Western Dvina - Lovat River Basins. Quaternary International 203(12): 52-66.

Mazurkevich A., Hookk D., Fassbinder J. 2009b. Magnetometry and susceptibility prospection on neolithic-early Iron Age sites at Sertey, NorthWestern Russia. ArcheoSciences Revue d'archeometrie, supplement, 33: 81-85.

Mazurkevich A., Kulkova M., Savel'eva L. 2012. Geoarchaeological issues of the Upper Dnieper Western Dvina River region (Western Russia): fieldtrip guide. Geomorphic processes and geoarchaeology. From Landscape Archeology to Archaeotourism. International conference, $\mathrm{Au}-$ gust 20-24, 2012. Moscow-Smolensk, Russia: 49-69.

Mroczkowska M., Pawłowski D., Gauthier E., Mazurkevich A., Luoto T.P., Peyron O., Kotrys B., Brooks S.J., Nazarova L.B., Syrykh L., Dolbunova E.V., Thiebaut E., Płóciennik M., Antczak-Orlewska O., Kittel P. 2021a. Middle Holocene Climate Oscillations Recorded in the Western Dvina Lakeland. Water 13(11): 1-24.

Mroczkowska A., Kittel P., Marcisz K., Dolbunova E., Gauthier E., Lamentowicz M., Mazurkevich A., Obremska M., Płóciennik M., Kramkowski M., Łuców D., Kublitskiy Y., Słowiński M. 2021b. Small peatland with a big story: 600-yearpaleoecological and historical data from a kettle-hole peatland in Western Russia. The Holocene 31(11-12): 1-16.

Mycielska-Dowgiałło E. 1995. Wybrane cechy teksturalne osadów i ich wartość interpretacyjna. In: E. Mycielska-Dowgiałło, J. Rutkowski (eds.) $B a-$ dania osadów czwartorzędowych. Wybrane metody $i$ interpretacja wyników. Uniwersytet Warszawski, Warszawa: 29-90.

Mycielska-Dowgiałło E., Ludwikowska-Kędzia M. 2011. Alternative interpretations of grain-size data from Quaternary deposits. Geologos 17(4): 189-203.

Paluszkiewicz R. 2011. Erosional-denudational valleys and their significance for the reconstruction of the late glacial environmental conditions (The Drawsko Lakeland, NW Poland). Quaestiones Geographicae 30(3): 71-81.

Paluszkiewicz R. 2014. Późnoglacjalna depozycja osadów dolinek wschodnich stoków Buślarskich Gór (Pojezierze Zachodniopomorskie). Landform Analysis 26: 85-93.

Panin A.V., Fuzeina J.N., Belyaev V.R. 2009. Longterm development of Holocene and Pleistocene gullies in the Protva River basin, Central Russia. Geomorphology 1008(1-2): 71-91.

Panin A., Fuzeina Y., Karevskaya I., Sheremetskaya E. 2011. Mid-Holocene gullying indicating extreme hydroclimatic events in the Centre of the Russian Plain. Geographica Polonica 84(1): 95115.

Passega R. 1964. Grain-size representation by CM patterns as a geological tool. Journal of Sedimentary Reasearch 4: 830-847.

Passega R., Byramjee R. 1969. Grain size image of clastic deposits. Sedimentology 13: 233-252.

Piech W., Kittel P., Mazurkevich A., Pavlovskaia E., Kazakov E., Teltevskaya Y., Błaszczyk K., Kotrys B. 2018. Cechy sedymentologiczne i warunki depozycji osadów stożka akumulacyjnego w dolinie rzeki Sertejki (Zachodnia Rosja). Acta Geographica Lodziensia 107: 215-238.

Piech W., Kittel A., Mazurkevich A., Kazakov E. 2020. Morphological characteristics of the erosion cuts system (gullies system) in the Serteyka River Valley, Western Russia. In: A. Młynarczyk (ed.) Środowisko przyrodnicze jako obszar badań. Bogucki Wyd. Nauk., Poznań: 183-198.

Podgórski Z., Szmańda J. 2004. Osady denne małych zbiorników zaporowych Pojezierza Chełmińskiego na tle osadów wybranych środowisk sedymentacyjnych. Rekonstrukcja i prognoza zmian środowiska przyrodniczego $\mathrm{w}$ badaniach geograficznych. Prace Geograficzne 200: 265278.

Poesen J. 2018. Soil erosion in the Anthropocene: Research needs. Earth Surface Processes and Landforms 43: 64-84.

Poesen J., Nachtergaele J., Verstraeten G., Valentin C. 2003. Gully erosion and environmental change: importance and research needs. Catena 91: 91133.

Racinkowski R., Szczypek T., Wach T. 2001. Prezentacja i interpretacja wyników badań uziarnienia. Wyd. UŚ, Katowice.

Ratajczak-Szczerba M., Paluszkiewicz R. 2015. Analiza sedymentologiczna osadów denudacyjnych w niszy niwalnej w krawędzi Pradoliny Toruńsko-Eberswaldzkiej. Landform Analysis 28: 7885.

Rodzik J., Ciupa T., Janicki G., Kociuba W., Tyc A., Zgłobicki W. 2008. Współczesne przemiany rzeźby Wyżyn Polskich. In: L. Starkel, A. Kostrzewski, A. Kotarba, K. Krzemień (eds.) Wspótczesne przemiany rzeźby Polski. Instytut Geografii i Gospodarki Przestrzennej Uniwersytetu Jagiellońskiego, Kraków: 165-228.

Rodzik J., Terpiłowski S., Godlewska A., Mroczek A. 2015. Contemporary development of an atypical bank gully in the Szwajcaria Polska Nature Reserve resulting from human activity (E Poland). Zeitschrift für Geomorphologie 59(2): 7-22. 
Sidorchuk A., Litvin L., Golosov V., Chernysh A. 2006. European Russia and Byelorus. In: J. Boardman, J. Poesen (eds) Soil Erosion in Europe. John Wiley \& Sons: 73-93.

Sinkiewicz M. 1989. Zmiany rzeźby terenu Pojezierza Kujawskiego pod wpływem procesów stokowych. Towarzystwo Naukowe w Toruniu.

Sinkiewicz M. 1998. Rozwój denudacji antropogenicznej w środkowej części Polski Północnej. Wyd. UMK, Toruń.

Smolska E. 2003. Cechy deluwiów na przykładzie osadów stokowych pagórka w okolicy Łopuchowa na Pojezierzu Suwalskim. Prace $i$ Studia Geograficzne 33: 45-57.

Smolska E. 2005. Znaczenie spłukiwania w modelowaniu stoków młodoglacjalnych (na przykładzie Pojezierza Suwalskiego). Wydział Geografii i Studiów Regionalnych UW, Warszawa.

Smolska E. 2007. Development of gullies and sediment fans in last-glacial areas on the example of the Suwałki Lakeland (NE Poland). Catena 71: 122131.

Smolska E. 2008. Badania sedymentologiczne współczesnych osadów deluwialnych i ich znaczenie w ocenie dynamiki procesów erozji gleby na przykładzie Pojezierza Suwalskiego. Przegląd Naukowy Inżynieria i Ksztaltowanie Środowiska 17(2): 202-212.

Starkel L. 1990. Stratygrafia holocenu jako interglacjału. Przeglad Geologiczny 38(1): 13-16.

Starkel L. 2005. Role of climatic and anthropogenic factors accelerating soil erosion and fluvial activity in Central Europe. Studia Quaternaria 22: $27-$ 33.

Starkel L., Michczyńska D., Krąpiec M., Margielewski W., Nalepka D., Pazdur A. 2013. Progress in the Holocene chrono-climatostratigraphy of Polish territory. Geochronometria 40(1): 1-21.

Stochlak J. 1996. Osady deluwialne nieodłączny efekt procesu spłukiwania i propozycja ich podziału. Ogólnopolskie sympozjum naukowe „Ochrona agroekosystemów zagrożonych erozją", Puławy-Lublin-Zwierzyniec, 11-13 września 1996 r. Prace Naukowe, Część 2. Instytut Uprawy, Nawożenia i Gleboznawstwa, Puławy: 111-132.

Szmańda J.B. 2010. Litodynamiczna interpretacja środowiska fluwialnego na podstawie wskaźników uziarnienia- przegląd wybranych metod. Landform Analysis 12: 109-125.

Szmańda J.B. 2011. Zapis warunków w uziarnieniu aluwiów pozakorytowych. Landform Analysis 18: 3-97.

Szwarczewski P., Rogóż-Matyszczak A., Zbucki Ł. 2020. Morphological and geochemical record of historical erosion on the example of small alluvial and deluvial fans accumulated on the Bug River terraces in the Neple area (Podlasie Lowland, eastern Poland). Baltica 3: 1-10.
Tanner W.F. 1958. The zig-zag nature of Type I and Type IV curves. Journal of Sedimentary Research 28(3):156-164.

Tarasov P.E., Savelieva L.A., Long T., Christian L. 2019. Postglacial vegetation and climate history and traces of early human impact and agriculture in the present-day cool mixed forest zone of $\mathrm{Eu}-$ ropean Russia. Quaternary International 516: 21-41.

Teisseyre A.K. 1994. Spływ stokowy i współczesne osady deluwialne w lessowym rejonie Henrykowa na Dolnym Śląsku. Prace GeologicznoMineralogiczne 43: 1-188.

Thorn C.E., Hall K. 2001. Nivation and cryplanation: the case for scrutiny and integration. Progress in Physical Geography 26(4): 533-550.

Tobolski K. 1998. Stan poznania historii lasów, jezior i torfowisk Borów Tucholskich. In: J. Banaszak, K. Tobolski (eds.) Park Narodowy Bory Tucholskie. Wyższa Szkoła Pedagogiczna w Bydgoszczy: 19-48.

Turkowska K. 1991. Rzeczne osady holoceńskie w świetle analizy wskaźników uziarnienia i zawartości węgla organicznego (na przykładzie doliny Neru w Lublinku koło Łodzi). In: A. Kostrzewski (ed.) Geneza, litologia $i$ stratygrafia utworów czwartorzędowych. Geografia 50, Wyd. UAM, Poznań: 353-366.

Twardy J. 1995. Dynamika denudacji holoceńskiej strefie krawędziowej Wyżyny Łódzkiej. Acta Geographica Lodziensia 89.

Twardy J. 2000. Deluwia neoholoceńskie - przykłady z Wyżyny Łódzkiej. Acta Geographica Lodziensia 78: 135-173.

Twardy J. 2003. Cechy sedymentologiczne neoholoceńskich osadów stokowych na Wyżynie Łódzkiej i ich wartość interpretacyjna. Prace i Studia Geograficzne 33: 25-44.

Twardy J. 2005. Gully erosion in middle Poland. In: J. Rejman, W. Zgłobicki (eds.) Human impact on sensitive geosystems. UMCS, Lublin: 129-142.

Twardy J. 2008. Transformacja rzeźby centralnej części Polski Środkowej w warunkach antropopresji. Wyd. UŁ, Łódź.

Twardy J. 2017. Holoceńska ewolucja niecek i dolin denudacyjnych w okolicach Łodzi w świetle dotychczasowych badań. Acta Geographica Lodziensia 106: 17-30.

Twardy J., Forysiak J., Kittel P. 2014. Evolution of vegetation, relief and geology in Central Poland under anthropopressure. In: E. Kobojek, T. Marszał (eds.) Origin and relief of Central Poland and its anthropogenic transformation. Łódź University Press: 57-94.

Tylman I. 2011. Morfogeneza dolinki denudacyjno-erozyjnej koło Mazowa (Dolina Wieprzy). Stupskie Prace Geograficzne 8: 109-128.

Udden J.A. 1914. Mechanical Composition of Clastic Sediments. Geological Society of America Bulletin 25: 655-744. 
Valentin C., Poesen J., Li Y. 2005. Gully erosion: impacts, factors and control. Catena 63: 132-153.

Vanmaerke M., Poesen J., Mele B.V., Demuzere M., Bruynseels A., Golosov V., Rodrigues Bezerra J.F., Bolysov S., Dvinskih A., Frankl A., Fuseina Y., Teixeira Guerra A.J., Haregeweyn N., Ionita I., Imwangana F.M., Moeyersons J., Moshe I., Samani A.N., Niacsu L., Nyssen J., Otsuki Y., Radoane M., Rysin I., Ryzhov Y.V., Yermolaev O. 2016. How fast do gully head cuts retreat? Earth-Science Reviews 154: 336-355.

Visher G.S. 1969. Grain size distributions and depositional processes. Journal of Sedimentary Petrology 39: 1074-1106.

Warrier A.K., Pednekar H., Mahesh B.S., Mohan R., Gazi S. 2016. Sediment grain size surface textural observations of quartz grains in late quaternary lacustrine sediments from Schirmacher
Oasis, East Antarctica: Paleoenvironmental significance. Polar Science 10: 89-100.

Wentworth C.K. 1922. A Scale of Grade and Class Terms for Clastic Sediments. Journal of Geology 30(5): 377-392.

Wieckowska-Lüth M., Gauthier E., Thiebaut E., Słowiński M., Krapiec M., Dolbunova E., Mazurkevich A., Maigrot Y., Danger M., Kittel P. 2021. The palaeoenvironment and settlement history of a lakeshore setting: An interdisciplinary study from the multi-layered archaeological site of Serteya II, Western Russia. Journal of Archaeological Science: Reports 40(B): 103219.

Zgłobicki W., Rodzik J., Superson J., Dotterwiech M., Schmitt A. 2014. Phases of gully erosion in the Lublin Upland and Roztocze region. Annales Universitatis Mariae Curie-Skłodowska, Sectio B 69(1): 149-162. 